\title{
An Interim Report on the Editorial and Analytical Work of the AnonymClassic Project
}

\author{
Beatrice Gruendler, ${ }^{1}$ Jan J. van Ginkel, Rima Redwan, Khouloud \\ Khalfallah, Isabel Toral, Johannes Stephan, Matthew L. Keegan, \\ Theodore S. Beers, ${ }^{2}$ Mahmoud Kozae, Marwa M. Ahmed*
}

In this collective article, members of the AnonymClassic project discuss various aspects of their work on the textual tradition Kalìla and Dimna. ${ }^{3}$ Beatrice Gruendler provides a general introduction to the questions being considered. This is followed by a number of short essays in specific areas, organized into three categories: codicology, literary history and theory, and the digital infrastructure of the project. Jan J. van Ginkel summarizes the challenges involved in editing the Syriac versions of Kalila and Dimna; Rima Redwan explains the AnonymClassic team's approach vis-à-vis the transcription and textual segmentation of Arabic manuscripts; Khouloud Khalfallah follows this with an overview of the types of data that are recorded for each codex that is integrated into the project; Beatrice Gruendler, in a second contribution, shares some preliminary results from the analysis of interrelationships among manuscripts; and Rima Redwan, also in a second contribution, discusses the sets of illustrations, or »image cycles", that are found in many copies of Kalila wa-Dimna. Moving into the realm of literary history and theory, Isabel Toral poses a range of questions relating to the status of Kalila and Dimna, as (arguably) anonymous in authorship and as a fundamentally translated book; Johannes Stephan explores the references to Kalila wa-Dimna found in various medieval Arabic scholarly works; and Matthew L. Keegan confronts the problem of the genre(s) to

* Correspondence details: Beatrice Gruendler, email: beatrice.gruendler@fu-berlin.de (corresponding author); Jan van Ginkel, email: Jan.van.ginkel@fu-berlin.de; Rima Redwan, email: rima.redwan@fu-berlin.de; Khouloud Khalfallah, email: khouloud.khalfallah@fu-berlin.de; Isabel Toral, email: itoral@zedat.fu-berlin.de; Johannes Stephan, email: Johannes.Stephan@fu-berlin.de; Matthew L. Keegan, email: mlkeegan@barnard.edu; Theodore S. Beers, email: theodore.beers@fu-berlin.de; Mahmoud Kozae, email: mahmoud.kozae@fu-berlin.de; Marwa M. Ahmad, email: marwa.ahmed@fu-berlin.de; Seminar for Semitic and Arabic Studies, Freie Universität Berlin, Fabeckstraße 23-25, 14195 Berlin, Germany.

1 Authors are listed in the order in which their contributions appear. Prof. Dr. Beatrice Gruendler is Principal Investigator of the ERC-Advanced Grant Project »Kalila and Dimna - AnonymClassic«, hosted at the Freie Universität Berlin, which also made this article possible.

2 The work of stitching together the various contributions, editing the prose, managing the figures, compiling the bibliography, etc. was led by Theodore S. Beers. Valuable editorial assistance was also provided by Agnes Kloocke, the AnonymClassic project coordinator.

3 This paper is based, in large part, on a joint presentation given by the AnonymClassic team at the conference Berlin ediert!, held at the Freie Universität Berlin on April 26-28, 2019. We thank the organizers, Prof. Dr. Glenn W. Most and Prof. Dr. Anne Eusterschulte, and all of the participants for their valuable feedback. 
which Kalila wa-Dimna might be assigned and the exceptional "promiscuity « of the text. The last section of the article, on digital infrastructure, contains two contributions: Theodore S. Beers describes a web application that the team has created to facilitate the consultation of published versions of Kalìla and Dimna, and, finally, Mahmoud Kozae and Marwa M. Ahmed offer a more comprehensive discussion of the digital tools and methods - specialized and in some cases developed »in-house« - on which the AnonymClassic project relies.

\section{Contents}

\section{Introduction - Beatrice Gruendler}

Part I - Codicology

The Syriac Manuscript Situation - Jan J. van Ginkel

Arabic Manuscript Transcription and Textual Segmentation - Rima Redwan

Manuscript Description and Classification - Khouloud Khalfallah

Image Cycles in Kalìla wa-Dimna Manuscripts - Rima Redwan

Manuscript Continua and Cross-Copying - Beatrice Gruendler

\section{Part II - Literary History and Theory}

Anonymity and Translation in Kalìla and Dimna - Isabel Toral

Constructing a Textual Tradition: Readers of Kalìla wa-Dimna - Johannes Stephan

Kalīla wa-Dimna: Genre and Literary Context - Matthew L. Keegan

\section{Part III - Digital Infrastructure}

An Online Reader App for Published Versions of Kalìla and Dimna - Theodore S. Beers

Toward Usable and FAIR Software for Arabic Textual Scholarship -

Mahmoud Kozae and Marwa M. Ahmed 


\section{Introduction - Beatrice Gruendler}

Kalila and Dimna ranks among both the most fascinating and the most elusive works in Arabic literature. ${ }^{4}$ Its enormous spread, being rewritten, versified, and translated in over forty languages (not only major ones but also outliers like Icelandic, Hungarian, and Madurese) in an area stretching from Spain to Malaysia, between the eighth and nineteenth centuries, makes it truly a work of global literature.

Important stations in this textual journey were its Sanskrit sources (the Panchatantra, the Mahäbhärata, and others, c. 300 CE); the first (lost) redaction to Middle Persian (i.e., Pahlavi, c. $550 \mathrm{CE}$ ); the translation into Syriac (probably around the end of the sixth century) and Arabic (c. $750 \mathrm{CE}$ ); and the propagation from Arabic to other languages, beginning with Greek, Persian, Hebrew, Latin, and Old Castilian (eleventh to thirteenth centuries).

These translations were often creative recompositions, notably in Persian (which saw multiple famous versions) and in Ottoman Turkish, carried out by well-known translators. The Persian Anvār-i suhayli (late fifteenth century) and the Ottoman Humāyūn-nāme (sixteenth century) are recognized as classics in their own right.

The Arabic version, or rather versions, became the sources of all later translations, but complete manuscripts exist only since the thirteenth century. Within a few generations after it was translated into Arabic, the work curiously falls apart in transmission, ${ }^{5}$ which makes it necessary to rely for a half millennium of the textual history (eighth to thirteenth centuries) on indirect transmission and early translations.

Beyond the cosmopolitan dissemination of Kalila wa-Dimna, it is in many ways unique within the Arabic tradition. First, it is the earliest extant work of overt prose fiction in high literature, unlike other early fiction in Arabic (much of it lost) that was perceived as popular literature. Second, it has (at least) two layers of meaning: while outwardly presented as a "mirror for princes", it is told in the form of fables, which require analogical decoding. Third, it also displays a sophisticated framing system, with up to five levels of narration down to very small units (amthāl, or analogical images, and hikam, or wisdom sayings). As such, it functioned as a modular system, whose elements could easily be substituted in iterative processes of cultural translation. In the course of its history in Arabic literature, this work became a popular "house book " on ethics and practical philosophy (and, in modernity, a children's book and schoolbook). ${ }^{6}$ This versatility made the text eminently adaptable, and it provided a source for quotations and entertaining tales that were culled from it and recast in smaller collections from the tenth century $\mathrm{CE}$ onward, surviving today in oral retelling.

Throughout this article, the work is referred to as Kalila and Dimna in broader contexts, and Kalila wa-Dimna when the focus is on Arabic versions. Our romanization of Arabic terms generally follows the system of the International Journal of Middle East Studies; and most dates are given in both the Islamic (AH) and the Julian/Gregorian (CE) calendars.

5 For a brief outline of the history of this text in the early period, see part II, the section by Johannes Stephan.

6 In other literatures (e.g., in Persian), its status could be quite different and change over the course of time. 
Finally, Kalila wa-Dimna is one of the first Arabic books, full stop. And it contains self-reflective passages about what it means to read a book - namely critically, searching for the deeper meaning, and then applying the acquired knowledge in real life. The text demonstrably invited interference by those who dealt with it. Being a book of wisdom and a guide to ethics and practical intelligence, it spoke to élites and commoners, adults and children. Through its (often graphic) substories it is also eminently entertaining. (One of our associate projects is to create, based on our research, a teaching tool for the Arabic language.) These many facets have been part of the book since its inception, making it irreducible to one "message«. Nor can it be assigned to one genre; rather, it shares traits with several. ${ }^{7}$

\section{Goals and Methods}

Much research on the Arabic Kalila wa-Dimna came to a grinding halt in the early decades of the last century - even as versions of the work in some other languages were being published and studied. ${ }^{8}$ A critical edition was never completed. The present project focuses on the Arabic versions, as among the least researched, most problematic, and also most urgent, since these served as the basis for all later versions.

The foremost obstacle is the text's mouvance, which takes place in writing and precludes a traditional stemmatic reconstruction. The so-called copyists (named or anonymous) rewrote the text in gradual or drastic ways and are de facto redactors - though they did not acknowledge their interference - as they acted not unlike those who versified or translated the work. In the course of the book's textual history, they overwrote the Arabic translator-redactor Ibn al-Muqaffa' (d. c. 139/757), so that Kalila wa-Dimna is a classic, but its authorship has effectively become anonymous. ${ }^{9}$

The project's goal is to document the text's motions, and not to attempt any sort of (ahistorical) reconstruction of a putative original - made impossible by a half-millennium interval between the composition (eighth century) and the earliest extant manuscripts (thirteenth century), and by their great variety from that point onward. This task is accomplished through a comprehensive gathering of data from all Arabic manuscripts, a more selective digitization and analysis thereof, ${ }^{10}$ the comparative display of manuscripts in a digital infrastructure, ${ }^{11}$ and studies of the text's salient aspects. ${ }^{12}$ The manuscripts convey not only the movement of the text itself, its changes, cuts and additions, ${ }^{13}$ and the text's interaction with illustrations ${ }^{14}$ but their paratexts also reveal much about the work's targeted readership and reception, including the spotty information culled from literary sources about the "dark"

7 On this point, see part II, the section by Matthew L. Keegan.

8 The project has gathered a substantial and growing number of these published versions. See part III, the section by Theodore S. Beers.

9 For a further discussion of these aspects (anonymity, authorship, and literary status), see part II, the section by Isabel Toral.

10 Our processes of manuscript transcription and analysis are described in part I, the sections by Rima Redwan and Khouloud Khalfallah, respectively.

11 On the software being adapted and developed for the project, see part III, the section by Mahmoud Kozae and Marwa M. Ahmed.

12 Some of the literary questions that we investigate are discussed in part II, the sections by Isabel Toral, Johannes Stephan, and Matthew L. Keegan, respectively.

13 See, for example, the review of the issues of continua and cross-copying in part I, the section by Beatrice Gruendler.

14 On image cycles in Kalila wa-Dimna manuscripts, see part I, the second section by Rima Redwan. 
phase before the appearance of complete manuscripts. ${ }^{15}$ The information gained from the manuscripts allows further observation of (a) the oscillation of the language between Classical Arabic and Middle Arabic (a hybrid language with its own features); (b) the agency of the so-called copyists, unacknowledged but visible in their interference in the text, as well as in paratexts, including tables of contents, not to mention the illustrations in a large proportion of the manuscripts; and (c) the combination (juxtaposed or merged) with other works in multiple-text manuscripts, helping to place Kalìla wa-Dimna in relation to diverse literary genres.

To cover the various linguistic, literary, and cultural facets, AnonymClassic has assembled a team of scholars on Arabic codicology, literary studies, the languages of the book's early versions (Syriac, Arabic, Persian), and computer science. Aspects not covered by the team (e.g., Sanskrit sources, Judeo-Arabic fragments, Latin, Old Castilian and Hebrew versions) are addressed by the project's partners. ${ }^{16}$

The concrete goal of AnonymClassic is to publish a comparative edition of selected manuscripts as the basis for a full, digitized edition of those manuscripts that best chart the motions of the text, to be accompanied by studies of aspects of its history, Middle Arabic, cultural translation and fictionality. This will be placed at the disposal of future research on Kalìla and Dimna in all its global diversity.

\section{Part I - Codicology}

The Syriac Manuscript Situation - Jan J. van Ginkel

In the sixth century CE, most likely at the Sasanian court, a Middle Persian collection of fables was created out of several Sanskrit collections. This Middle Persian Kalìla and Dimna was quickly translated into Syriac, most likely at the end of the sixth century, as there are no traces of the Arabic tradition in this text. The translator is named in a fourteenth-century source, the Catalogue of Biblical and Ecclesiastical Books of 'Abdisho' bar Brikha, as Budh the Periodeutes. ${ }^{17}$

This first Syriac translation survived in only one manuscript, copied by a certain deacon Hormizd near 'Amādiya in northern Iraq in 1524. After its rediscovery in Mardin in the library of the Chaldean Patriarchate in 1870, in the following years four copies were made for Western scholars. In 1895, the Chaldean patriarch brought the manuscript to Paris and gave it to the Societé Asiatique and René Graffin. After Graffin had taken it home with him, François Nau was able to write a brief description of the codex in $1911 .{ }^{18}$ Since then its whereabouts have been unknown. ${ }^{19}$ According to Nau, the manuscript consisted of 134 folios, but there were originally more. Kalila and Dimna fills the first 116 folios, but at least four additional folios have been lost from this section. ${ }^{20}$ It was written in an East Syriac script and had a

On the importance of studying the early »indirect transmission«, see part II, the section by Johannes Stephan. around 570 .

18 Nau, Manuscrit de Mgr Graffin.

19 It is possible that it ended up in the archive of the collection Patrologia Orientalis.

20 The last part (fols. 117-132) contained an apocryphal text, the Apocalypse of Paul (Visio Pauli). 
wooden cover. Red ink was used to indicate the names of "speakers«. Nau thought the copyist was probably a student, due to a number of irregularities and the generally unstable hand. There were many omissions and corrections in the text and in the margins. The margins also contained religious comments and scribal exercises.

Unlike the original, the four copies made for the use of scholars have been preserved. In 1870, Johannes Elia made the first copy in Mardin for Gustav Bickell, who used it as the basis for the first edition of the text. ${ }^{21}$ Although this copy, Göttingen, Niedersächsische Staats- und Universitätsbibliothek, MS Syr. 1, retains the text of some of the lost folios, the copyist seems not to have been fully able to understand the text. For example, he transcribed the East Syriac text in West Syriac script, but, at times, used West Syriac characters that looked similar to the East Syriac characters, rather than the real equivalent. ${ }^{22} \mathrm{He}$ also inserted some of the liturgical marginalia into the main text.

On the order of Eduard Sachau, three more copies were made in or near Mosul, after the Patriarch had moved the original manuscript there. ${ }^{23}$ In $1881-1882$, Jeremias Shamir made the second copy, Berlin, Staatsbibliothek, MS Syr. 104 (Sachau 139). In the colophon, the copyist indicates that the original had no diacritics or vowels, and that he therefore added them himself. This implies that all vocalization in the various manuscripts has been added by the later copyists and is, therefore, not necessarily authentic.

The third copy, Berlin, Staatsbibliothek, MS Syr. 105 (Sachau 150), again by Jeremias, dates from 1882 and has hardly any diacritics or vocalization, likely better reflecting the original. In 1883 (probably), a priest named Joseph made a fourth copy, Berlin, Staatsbibliothek, MS Syr. 106 (Sachau 149). Even though textually this copy provides us with the best version, it also has the most omissions. The copyist likewise added his own diacritics and may well have corrected or »improved « his Vorlage once or twice.

In addition to this Syriac version based on the Middle Persian text, there is also a second Syriac version of Kalila and Dimna based on an early Arabic text. ${ }^{24}$ An unknown translator produced this highly Christianized rendering in the tenth or eleventh century. It shares many elements of the early Arabic tradition with other translated versions like the Greek, the Hebrew, and the Old Castilian. This work, which has survived in a unique manuscript, now at Dublin, Trinity College, MS 1505, consists of 209 folios, with Kalila and Dimna being on the first 184 folios. The original manuscript dates from the thirteenth century, but large parts, most notably fols. 1-160, were restored in the fourteenth or fifteenth century. A second touch-up of several passages took place in around 1613. The text has many copying errors, which may have been caused, in part, by the extensive restoration. The origin of the manuscript is unknown, but it was most likely produced in northern Iraq. This codex is, in principle, no longer accessible, as the paper and vellum are brittle and, in addition, because it has been rebound too tightly. 
Making an edition based on these manuscripts presents many challenges, as both of the Syriac textual traditions have been severely mangled in transmission. Both Nau's description of the manuscript of the older version and the elaborate restoration of the manuscript of the newer version are clear indicators that the text is less well established than one might imagine based on published editions. It is therefore obvious that comparison with other versions of Kalila and Dimna, in all of the various linguistic traditions, is essential for editing the Syriac versions.

\section{Arabic Manuscript Transcription and Textual Segmentation - Rima Redwan}

The Arabic manuscripts of Kalila wa-Dimna pose complex questions of their own. In each manuscript, the number and order of chapters tends to vary. In most cases, the manuscripts are subdivided into seventeen or eighteen chapters, including the prefaces. For the process of our analysis, we have thus far focused our transcription work on six chapters or passages thereof. This initial selection, which covers the different phases of the book's textual history mentioned in the introduction above, consists of the following passages: "The Owls and the Crows" (Oc), originating from the Panchatantra; "The Mouse and the Cat» $(\mathrm{Mc})$, originating from the Mahäbhärata; "The King and His Dreams « (Kd), of unknown, perhaps Sanskrit origin; "Burzoy's Long Voyage" (Lv), originating from the Sasanian redaction; and the preface of Ibn al-Muqaffa' (Im) and the added tale "The Ascetic and the Guest" (Ag), both from the Arabic translation-redaction. ${ }^{25}$

Speaking in very general terms, in the process of manuscript transcription, two paradigms may be followed: diplomatic and normalized transcription. The diplomatic mode is used for retaining the orthography as-is (to the extent possible), while normalized transcription is meant to facilitate the presentation and comparison of the content. In practice, this is more of a spectrum than a binary. Editors strive to render their source materials faithfully, while introducing the degree of normalization required to achieve the other goals of their work. The balance that is struck will depend on a range of factors, and some compromise is usually unavoidable.

The approach implemented in our project falls well within the realm of normalized transcription. We are working with a large number of manuscripts, whose variations in textual content are already substantial, even before considering the finer points of orthography and scribal practice. It needs to be feasible for us to make meaningful comparisons (both manually and with digital tools) across this corpus of sources. And there are special challenges in the Arabic script, which is, to begin with, an abjad or "consonantary". The letters represent consonants and long vowels, while short vowels are left for the reader to understand from context - or, in some cases, indicated by means of diacritical marks. This means that reading requires a layer of interpretation that is not applicable in, for instance, the Latin alphabet. (There are other relevant features of the Arabic script, but this is perhaps the most obvious difference to emphasize to non-specialists.) We ensure that our transcription of Kalila wa-Dimna manuscripts follows a fairly uniform writing standard. The orthography is adjusted to Classical Arabic. It is important to note, however, that this normalization concerns neither morphology nor syntax. Cases of non-classical syntax, in which individual words still follow Classical Arabic, are kept in the transcription. Also retained are specific Middle Arabic morphological forms, such as non-classical verbal stems.

25 We use the chapter abbreviations of François de Blois: Burzōy's Voyage, 62. 
Our next step is the segmentation of the text, enabling literary analysis and comparison. Each chapter is segmented into semantic units, each of these being marked by a unique title. These units are based on the textual structure, reflecting separate, self-contained parts of monologue, dialogue, or third-person narrative, as well as wisdom sayings (hikam) and analogical images (amthāl). Based on these segmented units, synoptic digital editions are created. The primary tool that we use is the LERA platform, ${ }^{26}$ which supports editions of any number of digitized manuscripts of a given passage. The segmentation thus provides the possibility of gaining a comprehensive overview of the structure of each version of the text, as well as enabling a comparison with any other textual variant. With regard to the juxtaposition of variants among the manuscripts, this edition is our key procedure.

\section{Manuscript Description and Classification - Khouloud Khalfallah}

Considering the abundance of textual witnesses that we have gathered in the AnonymClassic project, we are confronted with the challenge of extracting and examining all aspects of the roughly 140 Kalila wa-Dimna manuscripts that we have identified, of which we have already obtained copies of around 95. To be able to meet this challenge, we have divided our process into three main workstreams.

First is a codicological study of all specimens. The aim of this study is to collect and ascertain the material data of the manuscripts. This includes general information about each codex, such as the relevant catalog information, the place of origin, the date of completion of the copy, the presence or absence of a colophon, etc. This survey also covers more detailed material aspects of each manuscript, for example, the dimensions of the paper, the number of lines per page, the existence of a frame, text division elements, and catchwords. Another important component in our description work is the script. Therefore, useful information about the script is added to this category, including the script type and execution, the colors of ink used by the copyist, the number of hands found in the copy, as well as the presence of diacritics and vowel marks, and other general aspects of the orthography. The linguistic features observed in a manuscript allow us to place its register between Classical and Middle Arabic. (The latter term is still insufficiently defined; we therefore make note of the specific features.) To finish work on this first stage, we also examine any illustrations, noting, among other characteristics, their frequency, placement, and style. In cases where illustrations are left blank or are substituted by legends, we take care to capture their format.

After collecting this information, we move to the second phase, which is to assess the version or form in which Kalila wa-Dimna appears in each manuscript. This part includes some basic information about the manuscript, such as the name of the copyist, the frequency and placement of any notes, and the patron associated with the copy (where applicable). An important aspect of this phase is to compare the chapter sequence found in the table of contents (if present) against the sequence that occurs throughout the text itself. All Kalila wa-Dimna manuscripts are then classified according to their actual chapter sequences. Finally, the incipit and explicit of a copy are noted to record its unique features. 
In the third part of this analysis, we focus on the content of the text, in order to be able to establish links among different copies. Through the segmentation system that we have designed, and thanks to the LERA platform that we are using, the process of comparing manuscript versions of select passages has become easier, clearer, and more precise. According to our interim observations and results, we evaluate the text in each chapter or passage based on its length (i.e., the number of semantic units contained) and structure (i.e., the sequence of semantic units). Within the same copy, we record all of the different phenomena of rewriting: cuts, additions, and changes. One interesting case of rewriting took place in London, British Library, MS Or. 3900 (hereafter L3900), a twelfth/eighteenth-century manuscript. In the first unit of Ibn al-Muqaffa"s preface, the copyist assumes authorship himself and drops the name of the Arabic translator-redactor and the title of the book. ${ }^{27}$

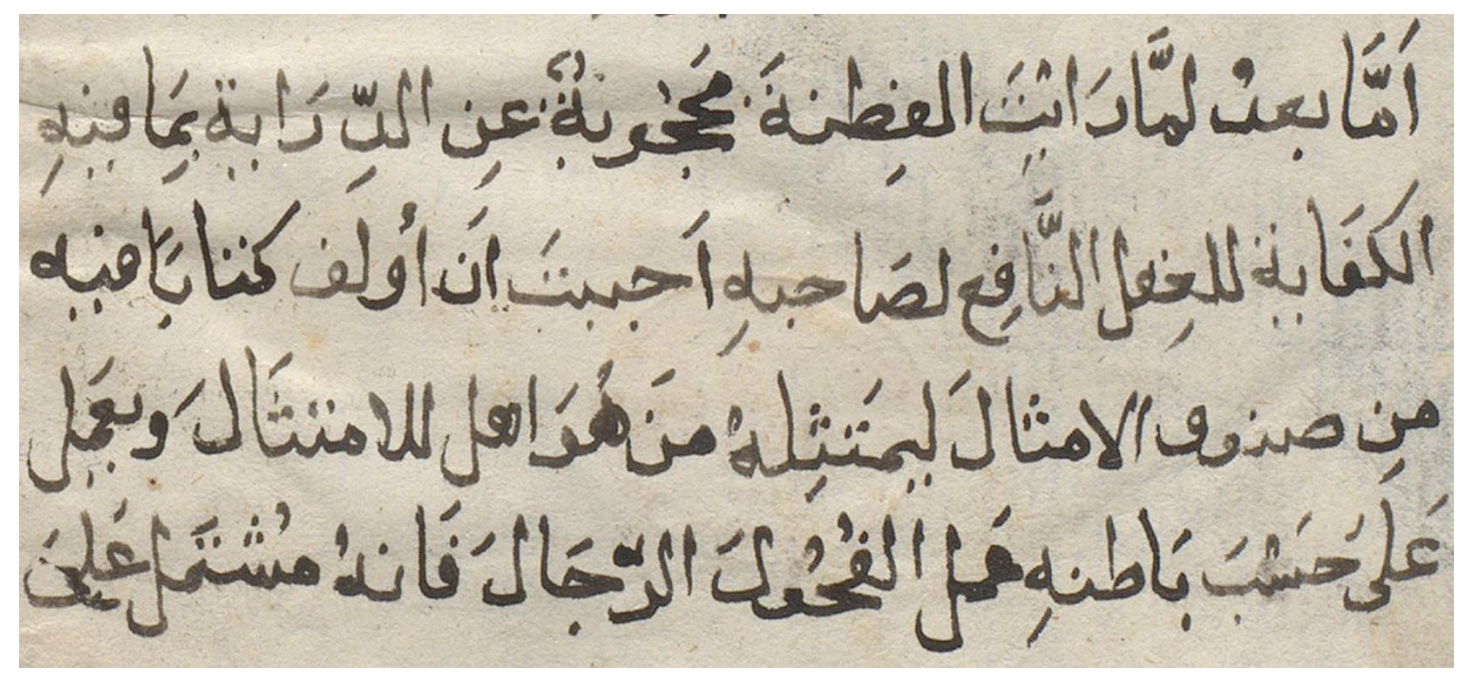

Fig. 1: London, British Library, MS Or. 3900 (1166/1752-1753), fol. 1v. "To proceed: When I saw intelligence becoming veiled from knowledge, which enables the mind to help him who possesses one, I wanted to compose a book with kinds of parables ..." pectively. 


\section{Image Cycles in Kalīla wa-Dimna Manuscripts - Rima Redwan}

Illustrations are an essential element in the textual transmission of Kalila wa-Dimna; they provide an important source of information for, among other things, a manuscript's dating (if it is otherwise undated), its place of production, and its relation to other codices.

From the preface of Ibn al-Muqaffa' (Im), it is clear that manuscripts of Kalila wa-Dimna were intended to be illustrated:

It was intended to show images (khayālät) of the animals in varieties of paints and colors (așbägh, alwān) to delight the hearts of princes and increase their pleasure, and also the degree of care that they would bestow on the work. ${ }^{28}$

Here, the question of the intended audience arises: What kind of reader did the author of the text aim to address? ${ }^{29}$ If this "author " was not Ibn al-Muqaffa" himself, one can assume that this passage represents the view of a copyist of the thirteenth century or earlier, since the earliest version of this textual unit is found in the manuscript Paris, Bibliothèque nationale de France, MS arabe 3465 (hereafter P3465), dated to the first part of that century. The copyist may thus have given an ex post explanation for the illustrations that were actually present in the manuscripts on which he was working.

An important aspect of the use of illustrations is their relation to the appeal of stories; namely, their number seems to correlate with the number of substories within a given chapter. A look at "The Lion and the Ox" (Lo), for example, shows that this is the chapter with the highest number of illustrations and also with the most substories (fifteen).

About one-third of the total 140 Kalila wa-Dimna manuscripts for which we have gathered data are illustrated, or display gaps in the text that were intended to be filled with illustrations. A significant feature is the inclusion of captions, which in some cases occur even without the described illustrations (with or without spaces left blank). For the most part, a caption or legend provides the reader not merely with the name of the illustrated character(s), but also with a short description of the matching narrative scene or part of the plot. Beyond offering information and linking image to text, such detailed captions serve a visual function and must be seen as an integral part of the picture.

Regardless of the illustrations' style, the depicted motifs intervene at specific points in the narrative and deserve detailed examination for the ways in which they structure the plot and highlight specific scenes of the frame narrative, main tales, and substories. Thus, the places where illustrations are inserted represent a key aspect of each version. The resulting sequence of images in a given codex - termed the "image cycle - becomes a factor in classifying the interrelation of manuscripts. A good example of manuscripts bearing similarities in image and text are Oxford, Bodleian Library, MS Pococke 400 (hereafter Pococke 400); Paris, Bibliothèque nationale de France, MS arabe 3467 (hereafter P3467); and München, Bayerische Staatsbibliothek, MS 616 (hereafter München 616). These three manuscripts originate from fourteenth-century Egypt or Syria. Not only in their motifs, but also in terms of the style and color palette, the similarities are striking. The three manuscripts' text is nearly identical, and they belong to the same image cycle. 


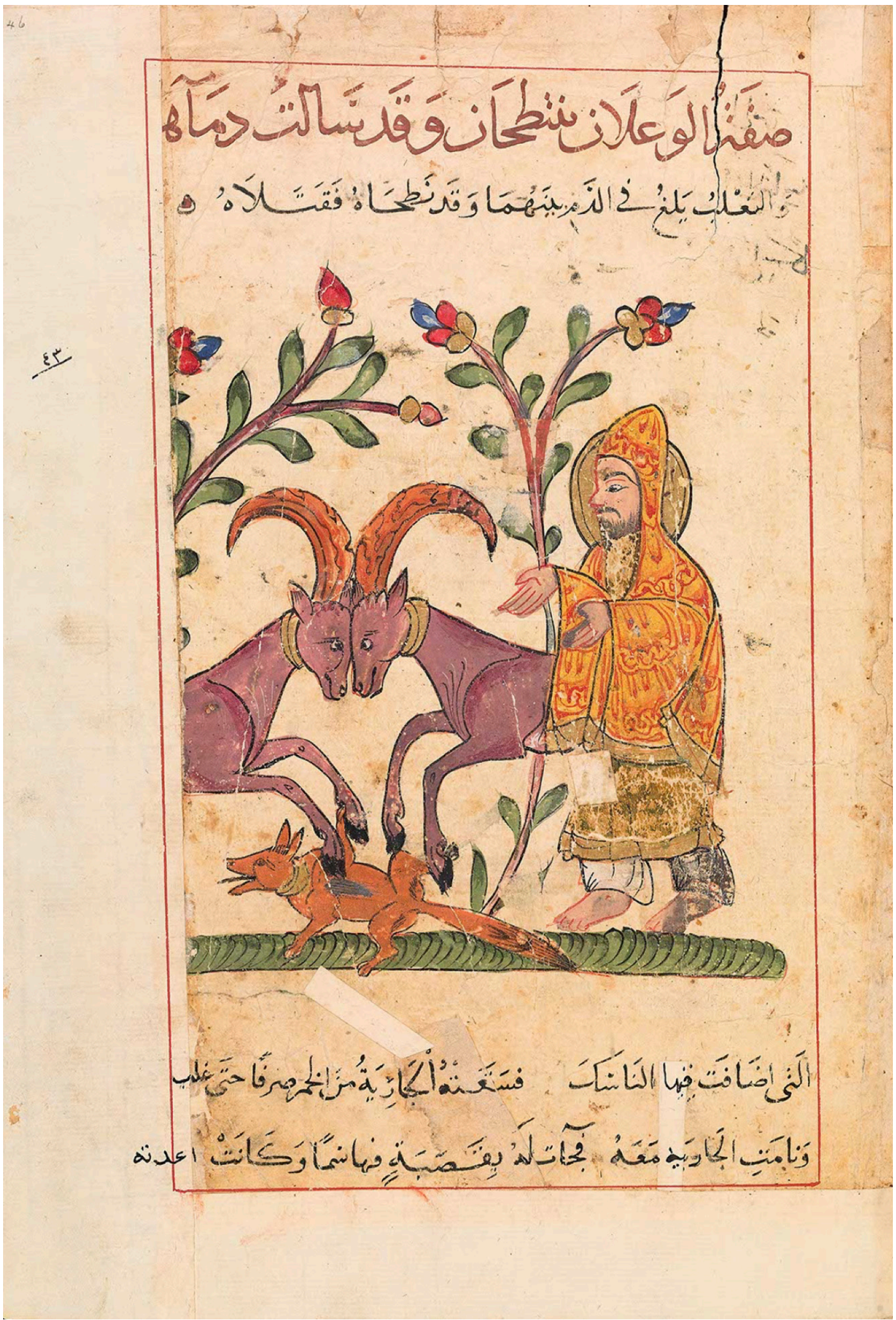

Fig. 2(a): Oxford, Bodleian, MS Pococke 400 (755/1354), fol. $46 r$. 


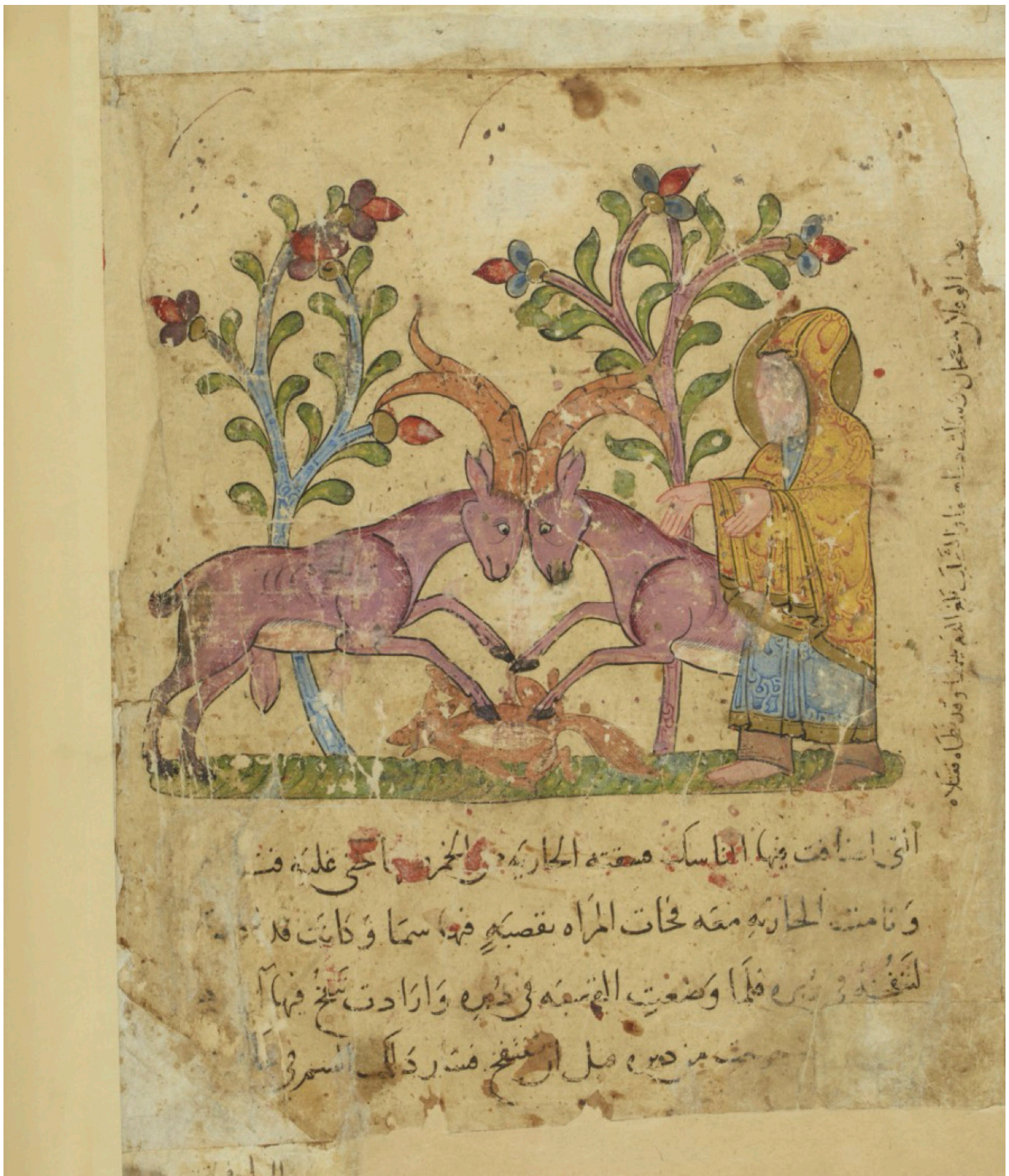

Fig. 2(b): Paris, BnF, MS arabe 3467 (c. $750 / 1350)$, fol. $15 v^{30}$

30 Images reproduced in this article from manuscripts at the Bibliothèque nationale de France are considered to be in the public domain. 


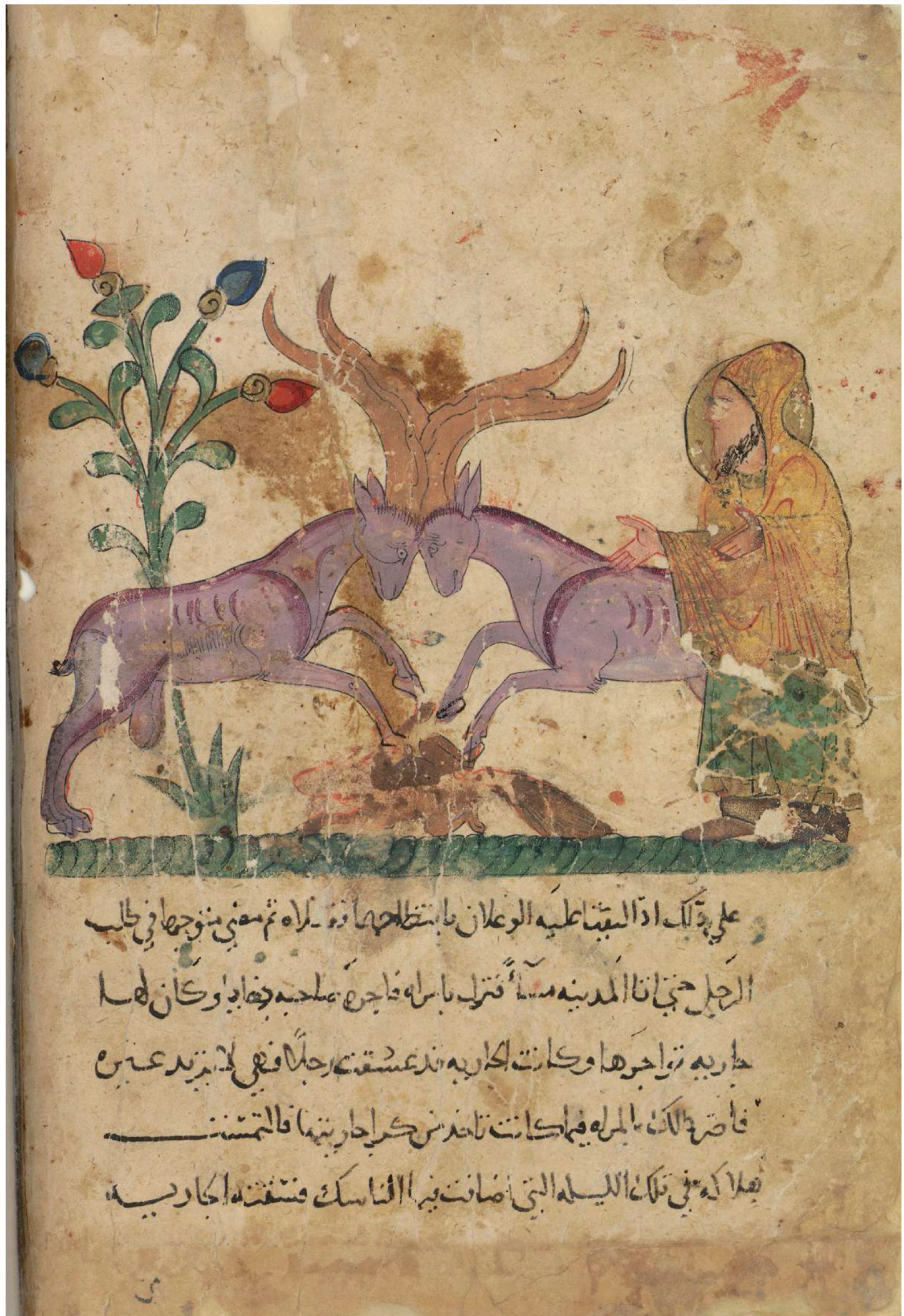

Fig. 2(c): München, BStB, MS 616 (first half of the eighth/fourteenth century), fol. $48 v$. 
A different kind of relationship among illustrations in Kalila wa-Dimna manuscripts can be demonstrated with a dramatic scene in the chapter "The King and His Dreams (Kd), in which the vizier returns to the king pretending to have executed the queen on his order. Here the same motif is illustrated, but carried out in completely different styles regarding the number of characters shown, their bodily proportions, dress, and posture, and the representation of the surroundings - from nothing (Rabat, Bibliothèque royale, MS 3655; hereafter Rabat 3655) via a thin line frame (Istanbul, Archaeological Museum, MS EY 344; hereafter Istanbul EY 344) and a prop (the king's veil in Cambridge, Corpus Christi College, Parker Library, MS 578; hereafter CCCP 578) to a fully realized architecture (Paris, Bibliothèque nationale de France, MS arabe 5881; hereafter P5881).

Aside from the dating of the manuscripts, each one contains a different version of the text. But these four are the only manuscripts found so far that include this motif of the vizier with the blood-smeared sword. In this context the question presents itself: Who decided in a given version which of the scenes should be illustrated? 


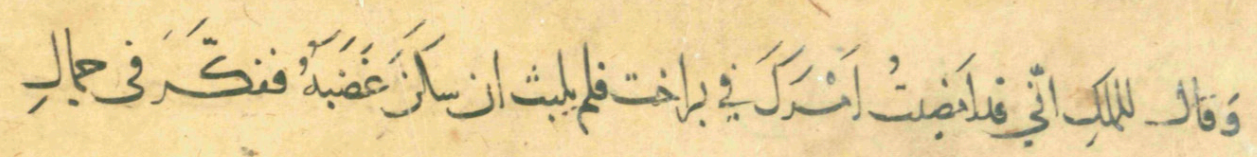

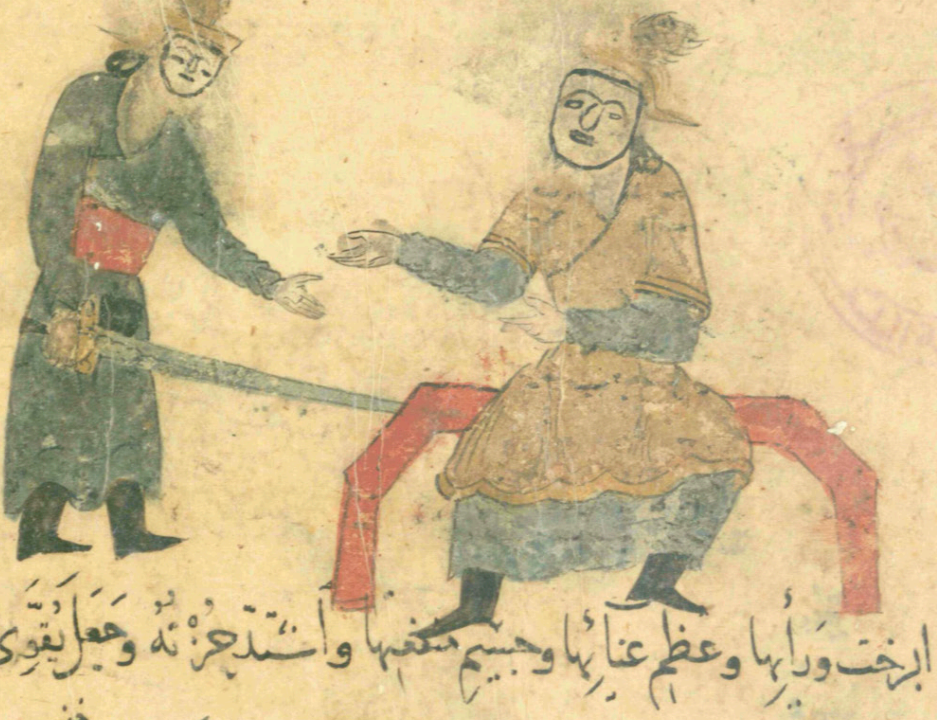

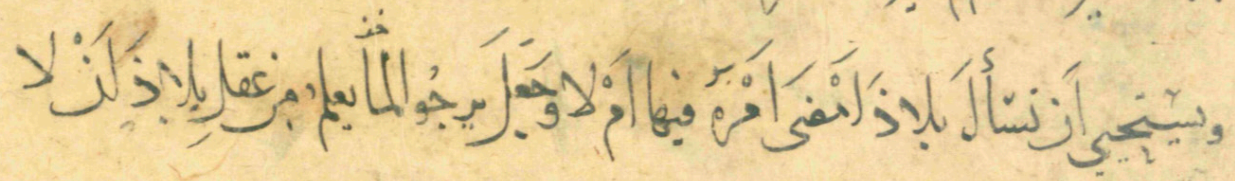

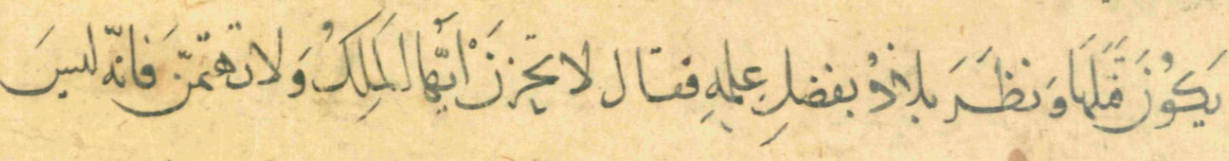

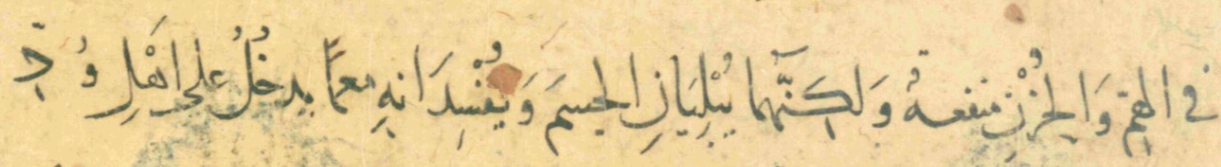

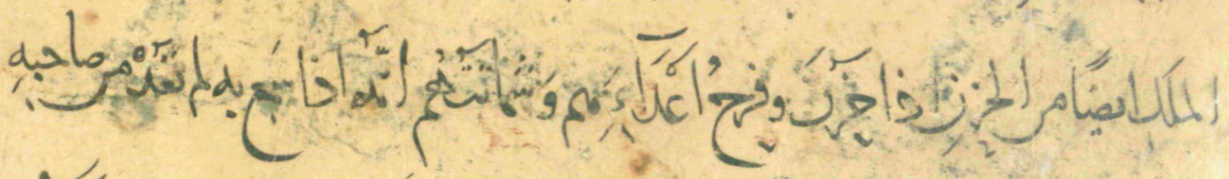

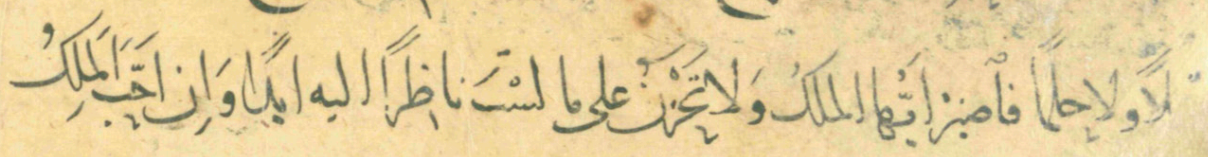
diclo

Fig. 3(a): Rabat, Br, MS 3655 (c. 1265-1280 CE), fol. 1oov. 


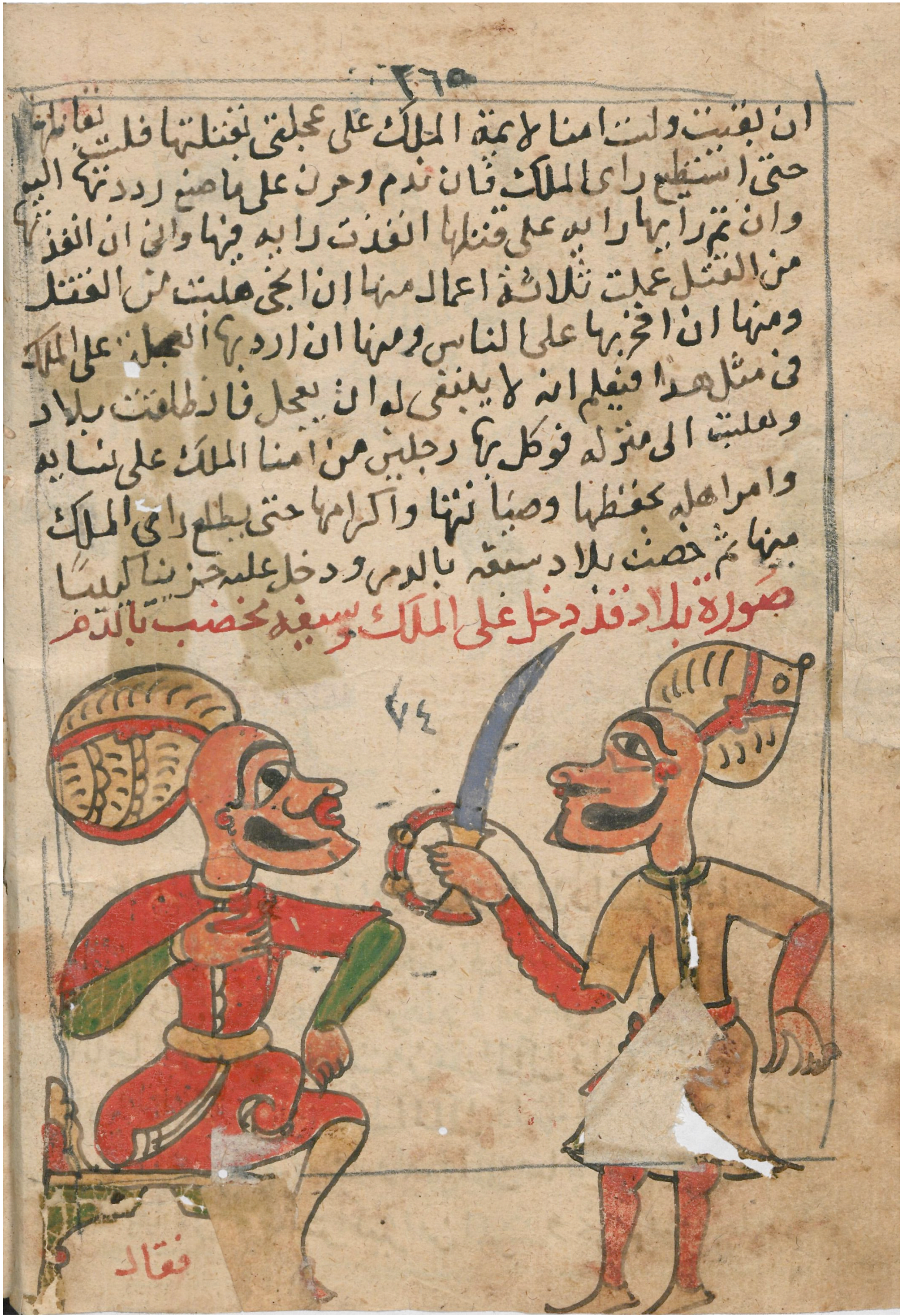

Fig. 3(b): Istanbul, AM, MS EY 344 (eleventh/seventeenth century), fol. $132 v$. 


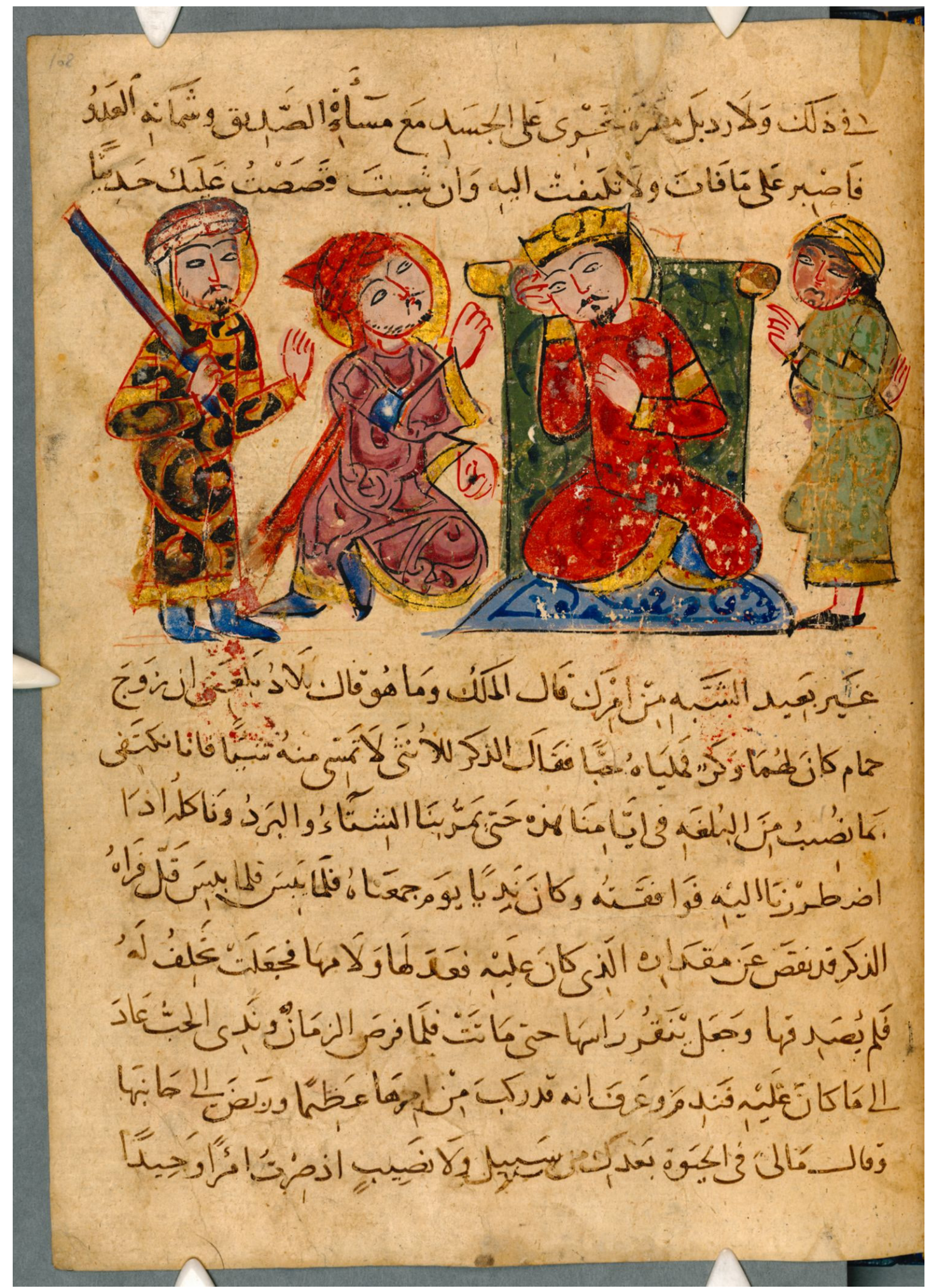

Fig. 3(c): Cambridge, CCC, Parker Lib., MS 578 (eighth/fourteenth century), fol. 108r. ${ }^{31}$

31 This image is covered by a Creative Commons NonCommercial license. 


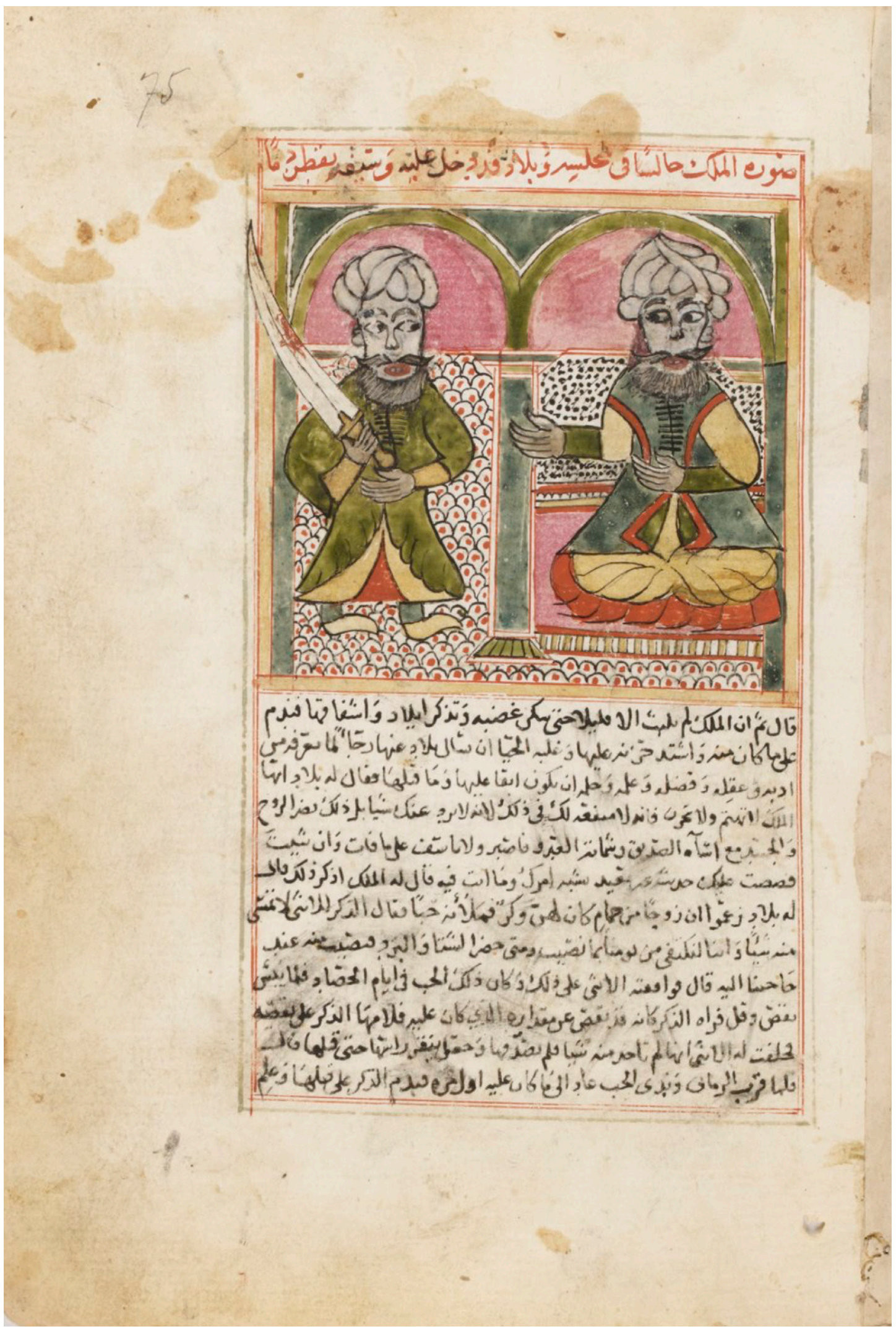

Fig. 3(d): Paris, BnF, MS arabe 5881 (1092/1681), fol. 75r. 
In sum, illustrations impart many kinds of information, providing evidence for dating and provenance, confirming relations among manuscripts, and offering important clues for literary analysis, as they highlight particular moments in the narrative. ${ }^{32}$

\section{Manuscript Continua and Cross-Copying - Beatrice Gruendler}

The Arabic manuscripts of Kalila wa-Dimna have so far been found to relate to each other in two major ways, namely, as continua or by cross-copying. Not all manuscripts fit these models; for example, there are a handful of early copies (eighth/fourteenth to ninth/fifteenth centuries) that stand apart. ${ }^{33}$ Also disregarded here are verbatim copies of known manuscripts, whose proportion is minor. What follows is an interim result, based on several dozen of the roughly 95 manuscripts that we have collected. Our conclusions will doubtless continue to evolve as the project moves forward.

\section{Continua}

For our purposes, a continuum is understood as a group of manuscripts that resemble each other in macrostructure and microstructure yet deviate in many places. ${ }^{34}$ In terms of the macrostructure, this means that the manuscripts of a continuum share most of their semantic units as well as their sequence. This being said, the sequence of units is fairly stable overall, and a restructuring, as happens in three of the six passages chosen for close analysis, defines a continuum. In terms of microstructure, i.e., the formulation within the individual units, differences are minor but numerous, and they vary in degree. Passages of near-verbatim identity across most manuscripts of a continuum alternate with new elements, ranging from single words or phrases to longer sentences. Two distinct continua have so far been defined; they are referred to after the libraries that hold particularly representative manuscripts.

The London continuum (hereafter L-c) is named after two manuscripts at the British Library - MS Or. 8751 (dated 799/1369) and MS Or. 4044 (dated to the ninth/fifteenth century; hereafter L4044) - and it also includes Istanbul, Ayasofya, MS 4095 (dated 618/1221). This continuum is likely the earlier of the two that we have identified, as it shares some structural features (the presence and sequence of units) with eighth/fourteenth-century copies that fall outside of it. In total, the manuscripts belonging to this group are fewer and mostly older than those of the other continuum. One unusual case is Paris, Bibliothèque nationale de France, MS arabe 3466 (dated 854/1450; hereafter P3466), as it belongs to the London continuum in later chapters (»The King and His Dreams«; »The Mouse and the Cat«; »The Ascetic and the Guest«), while matching the Paris continuum in earlier chapters (e.g., Ibn al-Muqaffa"s preface). ${ }^{35}$

32 For a study of such illustrations from an art-historical perspective, see Vernay-Nouri and Brac de la Perrière, Journeys of Kalila and Dimna.

33 These include Rabat 3655; Riyadh, King Faisal Center, MS 2536 (dated 747/1346; hereafter Riyadh 2536); and Istanbul EY 344.

34 The term "continuum « has been employed in a descriptive manner by Charlotte Touati for the relationship of Christian Arabic apocrypha. This is discussed in Schulthess, Manuscrits arabes, 7. Our usage is more tailored to the case of Kalila wa-Dimna.

35 Again, we follow the chapter shorthand of de Blois. The abbreviations of the chapters mentioned in this paragraph are as follows, in order: Kd; Mc; Ag; Im. 
The Paris continuum (hereafter P-c) is named after noteworthy representatives that are held at the Bibliothèque nationale, namely, MSS arabes 3465, 3473 (dated to the eleventh/ seventeenth century; hereafter P3473), and 3466 (albeit only in earlier chapters). It furthermore includes subcontinua with closer mutual proximity, namely, Riyadh, King Faisal Center, MS 2407 (dated 1103/1692) and Berlin, Staatsbibliothek, MS Wetzstein II 672 (dated 1246/1830), both similar to P3473; and Tunis, Bibliothèque nationale de Tunisie, MS 2281 (dated 1070/1660) and Beirut, Université Saint-Joseph, MS 0022(2) (dated 1263/1847), both similar to $\mathrm{P} 3466$. The Paris continuum proliferates at a later time, flourishing up to the nineteenth century, and it is better represented numerically.

For comparison, the two continua are shown based on the preface of Ibn al-Muqaffa, where the structural differences are most distinct (see Figs. 4(a) and 4(b) below). In L-c the position of the substory of the merchant and his partner occurs in the middle (units 90-97) and has no further tales following it, with the betraying partner remaining ashamed and silent regarding his erroneous theft. Units 96-97 belong solely to this continuum, as they are needed to end the substory here. This version of the preface gives emphasis throughout to the processes of critical reading, reflection, and the need to verify received information, as well as advising mental fortitude and moral stamina. (Other units specific to this continuum are $8,10,18,22-23,45-46,56,65$, and 68; omitted here are those units that appear in only one manuscript.) The conclusion of the chapter focuses on understanding the book, mentioning the preface's addition by the Arabic translator-redactor Ibn al-Muqaffa' and the importance of heeding his instructions. He speaks here in the first person (units 86-88). The double meaning of the fables is not explained, in keeping with the absence of further tales after the merchant and his partner.

$\mathrm{P}-\mathrm{c}$, by contrast, foregrounds and enhances the storytelling. The substory of the merchant and his partner is here placed at the end and followed by additional substories. In this version, the betraying partner admits his guilt, and this is followed by a dialogue between the two merchants, including an analogous subtale about a thief who confuses a jar of grain with a jar of gold (units 102-103). The merchants' dialogue and the conclusion of this internal frame (units 95, 98-101, and 106) are likewise specific to P-c. Further subtales of this continuum concern three brothers, the older two of whom squander their shares of the father's inheritance, while the youngest saves them with his own (units 108-113); and a fisher and a pearl (115-116). This version explains the reading of fables as a process of decoding, using the logical technical terms of premises (muqaddimāt) and conclusions (natä 'ij). The double-layeredness is taken up in the conclusion (unit 124), which characterizes the book as serving four goals for four different audiences: children, rulers, copyists and illustrators, ${ }^{36}$ and philosophers. The features of this version make it more entertaining, all the while justifying this entertainment as an outward manifestation hiding a deeper meaning.

36 See the quote about illustrations in part I, the second section by Rima Redwan. 


\begin{tabular}{|c|c|c|c|c|c|c|c|c|c|}
\hline & & & & & & & & \\
\hline & & & Paris 3465 & Paris 3473 & Paris 3466 & Paris 5881 & Ayasofya 4095 & London 8751 & London 4044 \\
\hline & & Chapter sequence & A & $B$ & $\mathrm{D}$ & C & C var. & C var. & A var. \\
\hline & & Date & 13th $\mathrm{c}$. & 17th $\mathrm{c}$. & $854 / 1450$ & $1092 / 1681$ & $618 / 1221$ & $799 / 1369$ & 15th $\mathrm{c}$. \\
\hline Unit no. & Unit type & Unit XML ID & P3465 & P3473 & P3466 & P5881 & A4095 & L8751 & L4044 \\
\hline 1 & $n$ & ImBaydabasComposition & & & & & & & \\
\hline 2 & g & ImUniqueBookOfWisdom & & 1 & & & & & \\
\hline 3 & n & ImIndiansCodeAnimalSpeech & 1 & 2 & 1 & & 1 & 1 & 1 \\
\hline 4 & $\mathrm{n}$ & ImBookReunitesAspects & 2 & 3 & 2 & & 2 & 2 & 2 \\
\hline 5 & $\mathrm{~m}$ & ImFarmerObtainsWeeds & & 4 & & & & & \\
\hline 6 & $\mathrm{n}$ & ImBooksUsesAreWisdomPlay & 3 & 5 & 3 & & 3 & 3 & 3 \\
\hline 7 & $\mathrm{~m}$ & ImBequeathedTreasure & 4 & 6 & & & 4 & 4 & 4 \\
\hline 8 & $\mathrm{n}$ & ImKnowledgeManyBranches & & & & & 5 & 5 & 5 \\
\hline 9 & $\mathrm{n}$ & ImReaderlgnoringCodeNoBenefit & 5 & 7 & 4 & & & & 6 \\
\hline 10 & $n$ & ImReaderToReflect & & & & 1 & 6 & 6 & 7 \\
\hline 11 & $\mathrm{n}$ & ImFastReaderNoBenefit & 6 & 8 & 5 & 2 & 7 & 7 & 8 \\
\hline 12 & $\mathrm{n}$ & ImIndiscriminateReaderNoBenefit & 7 & 9 & 6 & 3 & 8 & 8 & 9 \\
\hline 13 & $\mathrm{~m}$ & ImBuriedTreasureLost & 8 & 10 & 7 & 4 & 9 & 9 & 10 \\
\hline 14 & $\mathrm{ml}$ & ImDiscovererHiresHelp & 9 & 11 & & 5 & 10 & 10 & 11 \\
\hline 15 & $\mathrm{~m}$ & ImDiscovererLosesTreasure & 10 & 12 & & 6 & 11 & 11 & 12 \\
\hline 16 & h & ImReadingNotInDepthNoBenefit & 11 & 13 & & 7 & 12 & 12 & 13 \\
\hline 17 & $\mathrm{~m}$ & ImNutCrackedForBenefit & 12 & 14 & & 8 & 13 & 13 & 14 \\
\hline 18 & $n$ & ImGleanSecretKnowledge & & & & 9 & 14 & 14 & 15 \\
\hline 19 & $\mathrm{~m}$ & ImMemorizedSheetNoKnowledge & 13 & 15 & 8 & 10 & 15 & 15 & 16 \\
\hline 20 & $\mathrm{n}$ & ImUnderstandingReaderMustAct & 14 & 16 & 9 & 11 & 16 & 16 & 17 \\
\hline 21 & h & ImReasonSelfDenialNeverTooMuch & & 17 & 10 & 12 & 17 & & 18 \\
\hline 22 & ḥ & ImLifeNeedsCultureKnowledge & & & & 13 & 18 & & 19 \\
\hline 23 & $\mathrm{~m}$ & ImNoScorningCultureDeath & & & & & 19 & 17 & \\
\hline 24 & $\mathrm{~m}$ & ImCulturelsLikeSpark & & 18 & 11 & 14 & 20 & 18 & 20 \\
\hline 25 & ḥ & ImCultureRaisesKnowledgeForUseA & & 19 & 12 & 15 & 21 & 19 & 21 \\
\hline 26 & $\mathrm{~m}$ & ImManThrowsBallHigh & & & & & 22 & & 22 \\
\hline 27 & ḥ & ImBuildingRestsOnBasis & & & & & & & \\
\hline 28 & $\mathrm{n}$ & ImCultureRaisesKnowledgeForUseB & & & & & 23 & & \\
\hline 29 & $\mathrm{~m}$ & ImManNoticingBurglarFallsAsleep & 15 & 20 & 13 & 16 & 24 & 20 & 23 \\
\hline 30 & h & ImUnusedKnowledgelsIncomplete & 16 & 21 & 14 & 17 & 25 & 21 & 24 \\
\hline 31 & $\mathrm{~m}$ & ImKnowledgeActionlsTreeFruit & 17 & 22 & 15 & 18 & 26 & 22 & 25 \\
\hline 32 & ḥ & ImNoActionNoScholar & 18 & 23 & & 19 & 27 & 23 & 26 \\
\hline 33 & $\mathrm{n}$ & ImManLearnsOfLostTraveller & & & & 20 & 28 & 24 & 27 \\
\hline 34 & $\mathrm{~m}$ & ImInformedManTakesRiskyRoad & 19 & 24 & 16 & 21 & 29 & 25 & 28 \\
\hline 35 & $\mathrm{n}$ & ImManErrsDespitelnfo & 20 & 25 & & 22 & 30 & 26 & 29 \\
\hline 36 & $\mathrm{~m}$ & ImInformedPatientTakesBadFood & 21 & 26 & & 23 & 31 & 27 & 30 \\
\hline 37 & h & ImWhoDistinguishesHasNoExcuse & 22 & 27 & & 24 & 32 & 28 & 31 \\
\hline 38 & $\mathrm{~m}$ & ImSeeingManInDitchNoExcuse & 23 & 28 & 17 & 25 & 33 & 29 & 32 \\
\hline 39 & h & ImScholarMustTeachHimself & 24 & 29 & 18 & 26 & 34 & 30 & 33 \\
\hline 40 & $\mathrm{~m}$ & ImSourceBenefitsOnlyOthers & 25 & & 19 & 27 & 35 & 31 & 34 \\
\hline 41 & $\mathrm{~m}$ & ImSilkWormBenefitsOnlyOthers & 26 & 30 & 20 & & & & \\
\hline 42 & h & ImLearnerMustTameSoul & 27 & 31 & 21 & & & 32 & 35 \\
\hline 43 & h & ImThingsNeededForWorldlyLife & 28 & 32 & 22 & 28 & 36 & 33 & 36 \\
\hline 44 & h & ImNoBlamingFaultsOneHasToo & 29 & 33 & 23 & & & & \\
\hline 45 & h & ImActionPursuedForBenefit & & & & 29 & 37 & 34 & 37 \\
\hline 46 & $\mathrm{~m}$ & ImSomeReadersErrlnThis & & & & & 38 & 35 & 38 \\
\hline 47 & $\mathrm{~m}$ & ImPassiveReaderLikeBlind & & & & & & & \\
\hline 48 & $\mathrm{~m}$ & ImBlindBlamingBlind & 30 & 34 & 24 & & 39 & 36 & 39 \\
\hline 49 & $\mathrm{n}$ & ImNoBenefitByOthersHarm & & & & 30 & 40 & 37 & 40 \\
\hline 50 & $\mathrm{n}$ & ImPursuitMustHaveLimit & 31 & 35 & & 38 & 48 & 45 & 48 \\
\hline 51 & h & ImWhoStrivesAimlesslyFails & & & & 39 & & & \\
\hline 52 & h & ImJourneyWithoutLimitKills & 32 & 36 & & 40 & 49 & 46 & 49 \\
\hline 53 & $\mathrm{n}$ & ImNoSeekingTheUnreachable & 33 & 37 & & 41 & 50 & 47 & 50 \\
\hline 54 & $\mathrm{n}$ & ImNoPreferringHereToHereafter & 34 & 38 & & 42 & 51 & 48 & 51 \\
\hline 55 & h & ImDetachmentEasesDeath & 35 & 39 & & 43 & 52 & 49 & 52 \\
\hline 56 & h & ImNoDespairDespiteHardship & & & & & 53 & 50 & 53 \\
\hline 57 & h & ImTwoThingsSuitAll & 36 & 40 & 25 & 44 & 54 & 51 & 54 \\
\hline 58 & h & ImTwoThingsDoNotSuitAll & 37 & 41 & 26 & & & & \\
\hline 59 & $\mathrm{~m}$ & ImFireBurnsAll & 38 & 42 & 27 & 45 & 55 & 52 & 55 \\
\hline 60 & $\mathrm{~m}$ & ImFireWaterDoNotJoin & 39 & 43 & 28 & & & & \\
\hline 61 & n & ImGodsGiftUnexpected & 40 & 44 & & 46 & 56 & 53 & 56 \\
\hline 62 & $\mathrm{~m}$ & ImPauperWinsBurglarsGarb & 41 & 45 & & 47 & 57 & 54 & 57 \\
\hline 63 & $\mathrm{ml}$ & ImThiefTakesJar & 42 & 46 & & 48 & 58 & 55 & 58 \\
\hline 64 & $\mathrm{~m}$ & ImPauperCatchesThief & 43 & 47 & & 49 & 59 & 56 & 59 \\
\hline 65 & $\mathrm{~m}$ & ImIntelligentMustNotDespair & & & & 50 & 60 & 57 & 60 \\
\hline 66 & $\mathrm{n}$ & ImStrivingNotExpectingLuck & 44 & 48 & & 51 & 61 & 58 & 61 \\
\hline
\end{tabular}


Synopsis of semantic units in the chapter Im

\begin{tabular}{|c|c|c|c|c|c|c|c|c|c|}
\hline & & \multirow{2}{*}{$\frac{\text { Paris } 3465}{\mathrm{~A}}$} & \multirow{2}{*}{$\frac{\text { Paris } 3473}{\text { B }}$} & \multirow{2}{*}{$\begin{array}{c}\text { Paris } 3466 \\
\text { D }\end{array}$} & \multirow{2}{*}{\begin{tabular}{|c|} 
Paris 5881 \\
$C$
\end{tabular}} & \multirow{2}{*}{\begin{tabular}{c|} 
Ayasofya 4095 \\
C var.
\end{tabular}} & \multirow{2}{*}{\begin{tabular}{|c|} 
London 8751 \\
C var.
\end{tabular}} & London 4044 \\
\hline & & Chapter sequence & & & & & & & A var. \\
\hline & & Date & 13th $\mathrm{c}$. & 17th $\mathrm{c}$. & $854 / 1450$ & $1092 / 1681$ & $618 / 1221$ & $799 / 1369$ & 15th $\mathrm{c}$. \\
\hline Unit no. & Unit type & Unit XML ID & P3465 & P3473 & P3466 & P5881 & A4095 & L8751 & L4044 \\
\hline 67 & $\mathrm{n}$ & ImFortunateFewNoModel & 45 & 49 & & 52 & 62 & 59 & 62 \\
\hline 68 & $\mathbf{n}$ & ImStrivingMassesAreModel & & & & 53 & 63 & 60 & 63 \\
\hline 69 & $\mathbf{n}$ & ImStrivingForBenefitNotHarm & 46 & 50 & & 54 & 64 & 61 & 64 \\
\hline 70 & $\mathrm{~m}$ & ImDoveRepeatsLossOfChick & 47 & 51 & & 55 & 65 & 62 & 65 \\
\hline 71 & $\mathrm{~m}$ & ImJudgeOfLegalTricks & & & & & & & \\
\hline 72 & n & ImGuardingGodsMeasure & 48 & & 29 & 56 & 66 & 63 & 66 \\
\hline 73 & ḥ & ImStrivingForHereHereafter & 49 & 52 & 30 & 59 & 67 & 64 & 68 \\
\hline 74 & h & ImStrivingForHere & 50 & 53 & 31 & 58 & & 65 & 69 \\
\hline 75 & ḥ & ImStrivingForHereafter & & & & 57 & & & 67 \\
\hline 76 & ḅ & ImThreeThingsForWorldlyMan & 51 & 54 & 32 & 60 & 68 & 66 & 70 \\
\hline 77 & ḥ & ImThingsMarkingTheUseless & 52 & 55 & 33 & 61 & 69 & 67 & 71 \\
\hline 78 & n & ImManyAreCredulous & 53 & 56 & 34 & 62 & 70 & 68 & 72 \\
\hline 79 & $\mathrm{n}$ & ImBelievingInformation & & & & 63 & 71 & 69 & 73 \\
\hline 80 & $\mathbf{n}$ & ImCheckingOnesDesire & 54 & 57 & 35 & 64 & 72 & 70 & 74 \\
\hline 81 & $\mathbf{n}$ & ImCheckingInfoForTruth & 55 & 58 & 36 & 65 & 73 & 71 & 75 \\
\hline 82 & $\mathrm{~m}$ & ImContinuingOnWrongPath & 56 & 59 & 37 & 66 & 74 & 72 & 76 \\
\hline 83 & $\mathrm{~m}$ & ImLosingltchyEye & 57 & 60 & 38 & 67 & 75 & 73 & 77 \\
\hline 84 & $\mathrm{n}$ & ImHeedingDecreeResolve & 58 & 61 & 39 & 68 & 76 & 74 & 78 \\
\hline 85 & n & ImDoUntoOtherAsToOneself & 59 & 62 & 40 & 69 & 77 & 75 & 79 \\
\hline 86 & $\mathrm{n}$ & ImReaderMustHeedPreface & & & & 70 & 78 & 76 & 80 \\
\hline 87 & $\mathrm{n}$ & ImUnderstandingBookBenefits & & & & 71 & 79 & 77 & 81 \\
\hline 88 & $\mathrm{n}$ & ImThrowingStonelnDark & & & & & 80 & & \\
\hline 89 & $\mathrm{n}$ & ImTransAddsChapterToExplain & & & & 72 & 81 & 78 & 82 \\
\hline 90 & $\mathrm{~m}$ & ImMerchantStealsFromPartner & 60 & 63 & 41 & 31 & 41 & 38 & 41 \\
\hline 91 & $\mathrm{ml}$ & ImMerchantDevisesPlot & 61 & 64 & 42 & 32 & 42 & 39 & 42 \\
\hline 92 & $\mathrm{~m}$ & ImMerchantExecutesPlot & 62 & 65 & 43 & 33 & 43 & 40 & 43 \\
\hline 93 & $\mathrm{ml}$ & ImPartnerFindsGarb & 63 & 66 & 44 & 34 & 44 & 41 & 44 \\
\hline 94 & $\mathrm{~m}$ & ImMerchantStealsOwnBale & 64 & 67 & 45 & 35 & 45 & 42 & 45 \\
\hline 95 & $\mathrm{~m}$ & ImMerchantSeesErrorAtHome & 65 & 68 & 46 & & & & \\
\hline 96 & $\mathrm{~m}$ & ImMerchantSeesErrorlnShop & & & & 36 & 46 & 43 & 46 \\
\hline 97 & $\mathrm{~m}$ & ImMerchantSilentAboutBetrayal & & & & 37 & 47 & 44 & 47 \\
\hline 98 & $\mathrm{ml}$ & ImPartnerFearsAccusationMono & 66 & & 47 & & & & \\
\hline 99 & d & ImPartnerFearsAccusationDialog & 67 & 69 & 48 & & & & \\
\hline 100 & d & ImMerchantAdmitsTreachery & 68 & 70 & 49 & & & & \\
\hline 101 & d & ImPartnerRequestsExplaining & 69 & 71 & 50 & & & & \\
\hline 102 & d & ImPartnersParableMerchantThief & 70 & 72 & 51 & & & & \\
\hline 103 & $\mathrm{~m}$ & ImThiefTakesGrainForGold & 71 & 73 & 52 & & & & \\
\hline 104 & $\mathrm{~m}$ & ImThiefEyesJar & & & & & & & \\
\hline 105 & $\mathrm{~m}$ & ImThiefTakesGrain & & & & & & & \\
\hline 106 & d & ImMerchantForfeitsTrust & 72 & 74 & 53 & & & & \\
\hline 107 & n & ImReadingForParables & 73 & 75 & 54 & & & & \\
\hline 108 & $\mathrm{~m}$ & ImTwoBrothersSquander & 74 & 76 & & & & & \\
\hline 109 & $\mathrm{ml}$ & ImYoungestReflectsOnWealth & 75 & 77 & & & & & \\
\hline 110 & h & ImMisspendingRichlsPoor & 76 & 78 & & & & & \\
\hline 111 & h & ImRightSpendingEarnsPraise & 77 & 79 & & & & & \\
\hline 112 & h & ImFalseSpendingBringsRegret & 78 & 80 & & & & & \\
\hline 113 & $\mathrm{ml}$ & ImYoungestSpendsOnSiblings & 79 & 81 & & & & & \\
\hline 114 & $n$ & ImReaderMustTakeTime & 80 & 82 & 55 & & & & \\
\hline 115 & $\mathrm{~m}$ & ImFisherFindsEmptyShell & 81 & 83 & 56 & & & & \\
\hline 116 & $\mathrm{~m}$ & ImFisherMissesPearl & 82 & 84 & 57 & & & & \\
\hline 117 & $\mathrm{n}$ & ImSuperficialReadersMissMeaning & 83 & 85 & & & & & \\
\hline 118 & $\mathrm{n}$ & ImPleasureSeekingReaders & 84 & 86 & & & & & \\
\hline 119 & $\mathrm{~m}$ & ImGardenerNeglectsHarvest & 85 & 87 & & & & & \\
\hline 120 & d & ImReaderNeedsStaminaFocus & & 88 & 58 & & & & \\
\hline 121 & $\mathrm{~m}$ & ImPhilDiscipleTwoOwners & & 89 & & & & & \\
\hline 122 & $\mathrm{~m}$ & ImFriendsReachAgreementByCounseling & & & & & & & \\
\hline 123 & d & ImPrefaceToExplainHighAudience & & & 59 & & & & \\
\hline 124 & n & ImBookHasFourGoals & 86 & 90 & 60 & & & & \\
\hline 125 & $\mathrm{tm}$ & ImEndOfPrefaceBegContents & 87 & & 61 & & & & \\
\hline 126 & $\mathrm{tm}$ & ImEndOfPrefBegLvOrBu & & & & & 82 & & \\
\hline 127 & h & ImCultureLightsUpHeart & & & & & & & \\
\hline
\end{tabular}

Figs. 4(a-b): Tabulation of semantic units in the preface of Ibn al-Muqaffa; toward the end of which the Paris (left) and London (right) continua show clear divergence. 


\section{Cross-Copying}

One phenomenon that could be detected particularly with the aid of the synoptic editions of the LERA platform is that some copyist-redactors composed their versions out of several others in a process of cross-copying. ${ }^{37}$ This term has been preferred here over "contamination", which has long been employed in classical and medieval studies but is increasingly seen as outdated, and which presupposes a reconstructable original text (or »Urtext«). It is uncertain how these manuscripts came about, but given the great variety of versions already in the eighth/fourteenth century, it is plausible that copyists consulting various available Vorlagen for reproduction chose to combine their different facets into one comprehensive version. This recalls compilation techniques known from scholarly works, for instance in lexicography; but there all elements of different sources are assembled and recombined, whereas here the parts that are incorporated are carefully selected, while others are cut. Excluded here are cases in which versions appear to have been combined by error, such as Riyadh 2536, in which a missing page in Ibn al-Muqaffa"s preface is restored from a Vorlage of a different continuum, resulting in many duplications. The practice of cross-copying appears as early as the fourteenth century, in Pococke 400 and CCCP 578, but here it will be shown in P5881.

In the long version of the voyage of Burzoy to India (Lv), the Persian king gives a description of the kind of person to be chosen for the dangerous mission of retrieving the book of wisdom (unit 16, "LvKingSearchesScholar"; see the tabulation of manuscripts, Fig. 5, at the end of this section). Elements from different manuscripts are found combined in P5881 in this unit. The beginning is shared with Pococke 400: the scholar sought must belong to one of two categories - a scribe or a physician (immā kätiban tahriran aw țabìban faylasüfan). The middle part of the unit is shared with representatives of the Paris continuum (P3465, P3466, P3473) in various combinations: the individual must be educated and intelligent (rajul adīb 'ãqil) and an avid scholar (harịs 'alà țalab al-îlm / țalab al-ulüm), and must pursue his education diligently (mujtahid fi ... al-adab) and read philosophical books (kutub al-falsafa). The end is again parallel to Pococke 400, describing the advisors' setting out in search of the candidate.

In between, however, $\mathrm{P}_{5881}$ adds further facets, namely that this person must also practice speculative theology and exegesis (mutatābian fi l-nazar wa-l-tafsir), both being Islamic disciplines. And the copyist-redactor adds at the end that the advisors continued their search until they found a man fitting this ambitious description (talabū man hädhihi sifatuhū hattā wajadūhu). Some of these formulations have since been identified in CCCP 578, which implies that the cross-copying of P5881 was inspired by the same action of an earlier copyist-redactor. Here, and in many other units, the (anonymous) copyist-redactor of P5881 maximizes the narrative by adding aspects from various manuscripts, and potentially his own voice. Beyond incorporating elements from a number of units from different Vorlagen, the intervention in P5881 shows a recurrent focus on rational thinking and Islamic religion (however anachronistic this may be, in a tale about the Sasanian era).

There are various ways of cross-copying. P5881 represents a mosaic of many small parts. In the chapter of "The Long Voyage of Burzoy" (Lv), three or four changes per unit between different Vorlagen can be observed. Other manuscripts that show large-scale crosscopying of the mosaic style are Paris, Bibliothèque nationale de France, MS arabe 3471 (dated 1053/1643; hereafter P3471) and Oxford, Bodleian Library, MS Arab. 253 (dated 1227/1812).

37 The term was coined by Jean Dagenais, with reference to Old Castilian: Ethics of Reading, 132. 
Conversely, in CCCP 578 the cross-copying is done in larger blocks within units; and in Pococke 400, it is combined with targeted cuts of analogical images (amthāl) and wisdom sayings (hikam). A further variety appears in München 616, in a substory of the chapter of "The Owls and the Crows" $(\mathrm{Oc})$, in which passages within units and entire units are added in the margins, with symbols in the text indicating the places of insertion. The model for the supplied passages derives from the same continuum (close to P3466; München, Bayerische Staatsbibliothek, MS 618, dated 1046/1636; or L4044), and the additions enrich the narrative, a substory of marital deception, with graphic detail. In a further case, Istanbul, Ayasofya, MS 4213 (dated 880/1476), the cross-copying is openly declared: in the frame dialogue between the king and the philosopher in the chapter of "The Mouse and the Cat" (Mc), a unit from one Vorlage is followed, after the formula for adding variants (wa-qila, "and it has been said «), by a very different version from another..$^{38}$ Finally, cross-copying can be used to claim authorship, as in L3900, in which the copyist-redactor merges his incipit (similar to Riyadh 2536) seamlessly into the preface of Ibn al-Muqaffa' (in a version close to Pococke 400), whose first person in the final unit then appears to be the copyist-redactor himself. ${ }^{39}$ In the cases reviewed here, the cross-copying is substantial and clearly traceable, but this phenomenon may affect many more manuscripts, to varying degrees.

Some cross-copied versions became very popular: all of Pococke 400, P5881 and P3471 received verbatim copies, which indicates that readers appreciated the versions enhanced in this manner.

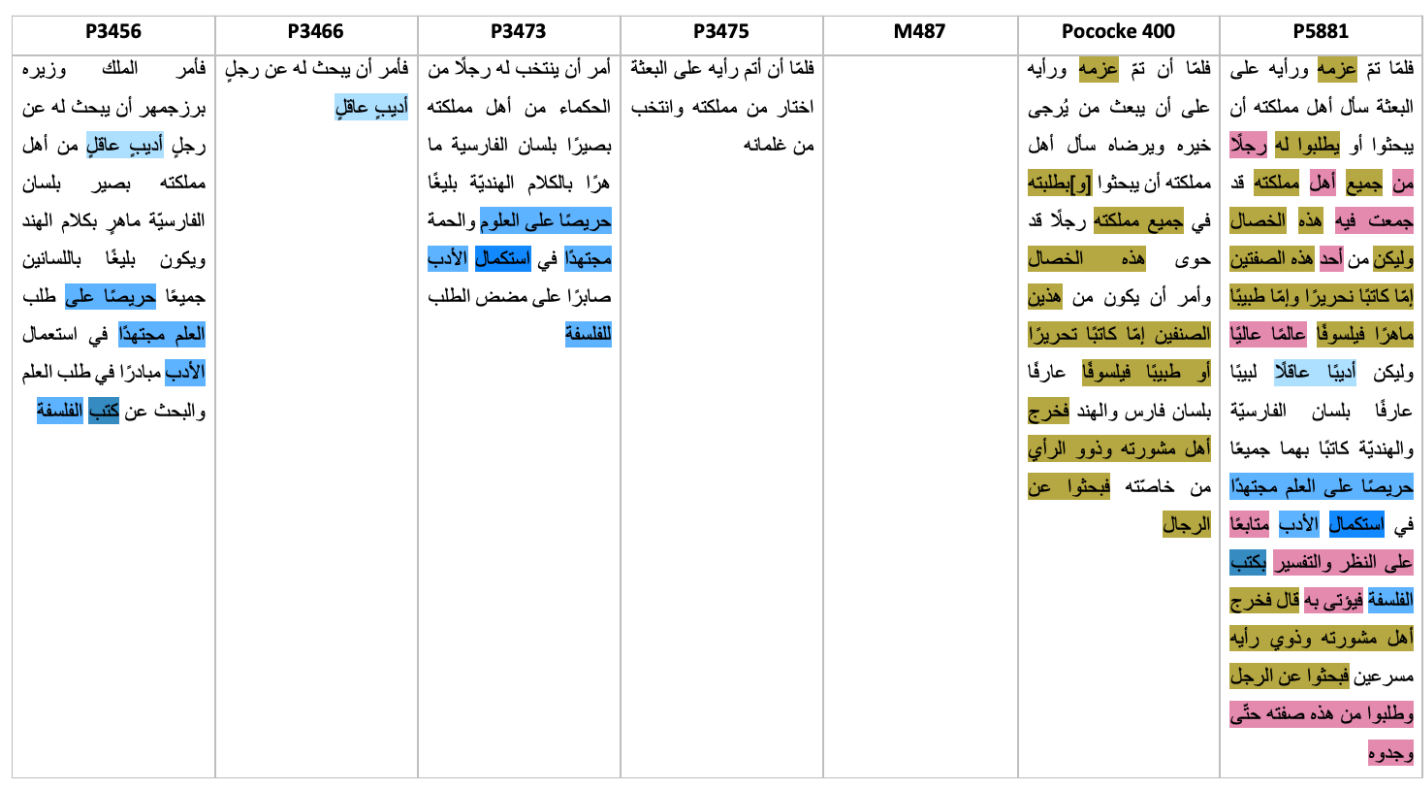

Fig. 5: An example of cross-copying in P5881 (rightmost column), with highlighting to show pieces that are shared with other manuscripts.

38 Istanbul, Ayasofya, MS 4213. In the PDF, see p. 103, left, line 7. (The foliation is not visible in the PDF.)

39 On this point, see also part I, the section by Khouloud Khalfallah. 


\section{Part II - Literary History and Theory}

\section{Anonymity and Translation in Kalila and Dimna - Isabel Toral}

The project AnonymClassic's acronym (i.e., "Anonym « and "Classic") stands for two conceptual fields that are highly relevant for our research, namely »authorship and anonymity" and »literary status and genre«. Our goal is to contribute to a deeper understanding of these issues in premodern Arabic literature by investigating the history of this extremely popular text over time, and by reconstructing the dazzling variety of versions in Arabic and other languages and cultures. Based on these results, we aim to engage in a wider discussion with other premodern European and non-European philologies, and to explore the extent to which these concepts and discussions from modernist philologies are transferable to our material, and/or how they should be modified. The following are a few of the questions that we address:

1. Authorship and anonymity: To what degree can we speak of Kalila wa-Dimna as an "anonymous « text? Do we find names of "authors" attached to the text, and if so, in what form/function? Or do we rather detect "anonymous interventions by copyists and redactors? What happens to these names and authorial positions/functions over time and when transferred to other contexts? Can we observe relevant changes?

2. Status and literary genre: What is the status of Kalila wa-Dimna in Arabic literature? When does it start to be a "classic", and what does that mean? Can we detect certain structural or thematic features of Kalila wa-Dimna that explain its striking popularity and translatability? Does the text lose or keep its status as a foreign/translated text (or as a classic) over time, and when transferred to other contexts? What can we say about the diverse functions or "Sitz im Leben" of this text (e.g., as a »mirror for princes «, as a popular and entertaining collection of tales, as esoteric animal fables, as a cultivated fictional text, etc.)?

Regarding the first set of issues, with anonymity and authorship in Kalila wa-Dimna - i.e., what we can know about the author(s), and in what sense Kalila wa-Dimna can be considered an anonymous text - the following are some provisional reflections.

To start with, the authors of the Indian »original « book are mentioned as anonymous (nameless) "composers " in most versions of the preface, there described as "Indian sages". The original book is thus presented as going back to an ancient, distant, and exotic (Indian) past, which makes the book a valuable "luxury item « imported from the East. In contrast to authorization techniques in Islamic canonical literature, names seem not to be relevant to enhance the value of this work. The reality, as far as it can be determined, is that Kalila and Dimna goes back to a combination of Indian tales drawn from the Panchatantra, the Mahäbhärata, and other sources, whose authors are not known by name.

The copyist-redactors of the Arabic manuscript versions, on the other hand, are creative composers and rewriters of the text, and should be regarded as true authors. However, though they are frequently known by name (conventionally recorded in the colophons of manuscripts), they are never mentioned as authors; their individual agency can be detected only by reconstructing their massive interventions (as »silent personae«) in the text. This means that their agency remains almost invisible and is not attached to their names. The situation rather resembles the work of the anonymous craftsman who has really designed a 
house but stays in the background, while the architect is foregrounded. It is an important part of the project's research to uncover the copyists' "silent « activity and investigate their role in the textual history. ${ }^{40}$

Besides, we find several names attached to the text, who appear as intermediaries and "translators " between the Indian original and the Arabic text as we have it. For instance, there is Burzoy, the physician who allegedly translated the text from Sanskrit to Middle Persian, and whose voyage to India and intellectual biography are extensively recorded in two chapters of Kalìla and Dimna (Sv/Lv and Bu). Second, there is Ibn al-Muqaffa', a well-known personality of early Arabic literature, famous as an Iranian convert to Islam and author of various translations from Middle Persian. He appears prominently as the translator of Kalila and Dimna from Middle Persian into Arabic, and as the author of one of the prefaces to the text (Im). Both names (Burzoy and Ibn al-Muqaffa') are retained in most manuscripts and are identifiable personae, probably because they are also the protagonists of distinct chapters. Another important figure is the Persian minister Buzurgmihr - also a notable character in Arabic literature as advisor to the wise Sasanian king Khusraw Anūshìrwān - who becomes the author of the Persian frame narrative (he tells the story of Burzoy's life, i.e., Bu).

The complex reception history in Arabic culture - Kalila wa-Dimna was extensively quoted, paraphrased, versified, imitated, and alluded to - shows that the text was frequently connected with the name of Ibn al-Muqaffa'. But the work is also often referred to in ways that de-emphasize authorship, e.g., as "the Indian book " (Kitäb al-Hind). ${ }^{41}$

The manuscripts also evidence other authorial attributions. In L3900, as has been mentioned in earlier sections by Khouloud Khalfallah and Beatrice Gruendler, the copyist has suppressed Ibn al-Muqaffa' altogether, and, inspired by another manuscript, he assumes authorship himself. He drops his source's author and title ('Umar b. Dāwūd b. al-Shaykh Sulaymān al-Fārisī, Siyar al-mulūk, preserved in Istanbul, Sultan Ahmed III Library, MS 3015, dated 727/1327 - itself a redaction-retroversion from Persian) and puts himself in their place. He seems to rely in this on the earlier, similar case of Riyadh 2536, in which the (anonymous) copyist has likewise incorporated material from 'Umar al-Fārisī, but still mentions him by name. In other instances (e.g., P3466 and later manuscripts), it is Baydabā' - the philosopher from the Indian frame story - who is said to have composed the book as a collection of animal tales. Thereafter, the vizier Buzurgmihr would have added a preface on the book's benefits (Im, elsewhere ascribed to Ibn al-Muqaffa'), and another on the voyage of Burzoy (Lv).

Regarding the second set of issues, with the status of Kalila and Dimna as a translated text, one may say that one of the constant features that we find in almost all versions of the work (in Arabic and beyond) is that it is presented as a translation from a foreign culture, namely India, and not as an original product of the respective culture. One noteworthy exception is the case of Abù 'Abdallāh al-Yamanì (d. c. 400/1009-1010), the author of an early metatextual commentary on the book, who considers it an original creation by Ibn al-Muqaffa. ${ }^{42}$ There are other translated texts in premodern Arabic literature that tend rather to conceal or downplay their foreign origins. One example is the Kitāb al-Täj fì akhlāq al-mulūk, which

40 This issue is also discussed in part I, the section by Beatrice Gruendler.

41 See part II, the section by Johannes Stephan.

42 For more on al-Yamani’s response, see part II, the sections by Johannes Stephan and Matthew L. Keegan, respectively. 
was attributed to al-Jāhiz (d. 255/868-869), but is in fact based on a creative compilation of translated texts from Middle Persian that were put together by Muhammad b. al-Hārith al-Taghlibi/al-Tha'labi (d. 250/864) ${ }^{43}$ Also worth noting are the Arabic versions of the Barlaam and Josaphat legend, i.e., Bilawhar wa-Büdhäsaf. This work was translated, again most likely from Middle Persian, and it ultimately derives from Indian stories about the life of the Buddha. Despite the clearly exotic surrounding of Bilawhar wa-Büdhäsaf, however, the text lacks a preface to explain whether and how it came to be translated. ${ }^{44}$

In the case of Kalila and Dimna, it was apparently important to maintain the translated status; and this circumstance might also explain why the translators Burzoy and Ibn al-Muqaffa seem to be the real protagonists and "authors". The significance of the trope of translation for the cultural value of Kalila and Dimna raises several other important questions that we intend to address in the context of translation studies (particularly those theories that focus on the sociocultural aspects of translations and study their function and connectedness within a given cultural system). ${ }^{45}$ Was Kalila and Dimna used as a vehicle to introduce cultural innovations (e.g., the »mirror for princes« genre, fables, prose literature, even fiction itself)? Was it translated for representational objectives (i.e., the appropriation and incorporation of useful foreign wisdom)? Did the trope of translation facilitate the evasion of censorship via the transfer of authorial responsibility? If so, what might be the subversive aspects of Kalila and Dimna?

\section{Constructing a Textual Tradition: Readers of Kalila wa-Dimna - Johannes Stephan}

Kalila and Dimna's Arabic translation from the mid-second/mid-eighth century and its wide dissemination generated a multitude of citations and cross-references within premodern scholarship in Arabic, which are of interest for a number of reasons.

First, these references carry some significance for the edition project, considering that the oldest manuscript copy of Kalila wa-Dimna available dates to the early thirteenth century. ${ }^{46}$ Hence references prior to that date may provide us with hints of what earlier versions might have looked like. Early references range from a few quotes in the Book of Animals by the polymath al-Jāhiz (d. 255/868-869) to the global historian al-Ya'qūbì (d. 284/897), who provides a first table of contents, up to the bookseller-bibliographer Ibn al-Nadim (d. 380/990), who contextualizes Kalila wa-Dimna among books of Indian wisdom. ${ }^{47}$ Before the thirteenth century, one notices not only that the cross-references to similar passages diverged from author to author, but also that the book itself was referred to by different titles: some spoke of "an" or »the Indian book«; others quoted from "Indian wisdom" or simply from the "parables

43 Schoeler, Verfasser und Titel. See also Marlow, Advice and advice literature.

44 See Toral-Niehoff, Legende "Barlaam und Josaphat«; and Forster, Barlaam and Josaphat.

45 See, for example, Toury, Descriptive Translation Studies.

46 See de Blois, Burzōy's Voyage, 3.

47 Al-Jāhịiz, Kitāb al-Hayawān, ed. Hārūn, 6:330, 7:92-100; al-Ya'qūbī, Tärīkh, ed. Houtsma, 1:97-99; Ibn al-Nadīm, Kitäb al-Fihrist, ed. al-Sayyid, 2:325-326. See also al-Ya'qübī, Works of Ibn Wädih al-Ya qüüì, ed. and trans. Gordon et al., 2:351-352. For more on Ibn al-Nadim's report, see part II, the section by Matthew L. Keegan. 
of Kalila wa-Dimna«, often without referencing Ibn al-Muqaffa' as the book's initial Arabic translator. ${ }^{48}$ Such amorphous treatment invites us to consider a set of questions: What is Kalila wa-Dimna? How many chapters did it contain initially? How was it presented to its readers? And how did that readership delineate the textual boundaries of the "Indian book«?

Second, looking at the plurality within the rich corpus of references, the diverse semantic level is also conspicuous. In other words, the interpretations, the status, and the value ascribed to Kalila wa-Dimna did diverge considerably in the first five centuries of its reception. Philosophers such as Ibn Sīnā (d. 428/1037) and Ibn Rushd (d. 595/1198), in their commentaries on Aristotle's Poetics, focused on the fabulistic features, hence the fictive character of its stories ${ }^{49}$ Some littérateurs such as Ibn Qutayba (d. 276/889), Ibn Abī 'Awn (d. 322/934), and Ibn 'Abd Rabbih (d. 328/940) concentrated on the parables and gnomic sayings, which, in their anthological works, are surrounded by quotes from the prophetic tradition and the Qur'an, Arabic poetry, and the wisdom of other civilizations, such as the Persians and the Greeks. ${ }^{50}$ Furthermore, some others, such as the first known Kalila wa-Dimna commentator, ${ }^{51}$ Abū 'Abdallāh al-Yamanī (d. c. 400/1009-1010), recognized that the book's gnomic sayings and parables might be helpful to buttress qur'ānic morality, but underlined that Arabs had expressed the same wisdom before Islam, albeit in verse. Also, according to al-Yamani's view, one may even suspect that the book was altogether an invention of Ibn al-Muqaffa, adapting ancient Arabic poetry, which after all - like Kalìla and Dimna - carries moral messages of a universal character, accessible to different language communities..$^{52}$ Another figure, al-Bīrūin (d. 440/1048), chose to cast some doubt on the Arabic translator's reliability in faithfully transmitting Indian wisdom, being critical of Ibn al-Muqaffa"s alleged heretical intentions and aware of the differences among the Sanskrit, Persian, and Arabic versions of the book..$^{53}$ In sum, whereas some authors characterize the work as consisting of fabulistic content or take it as a book of wisdom sayings, others shed light on its purportedly doubtful transmission history.

The different perspectives on the book's ontological status suit its diverse and complex structure. Part of Kalila wa-Dimna's changing nature is its framing by several prefaces which are attributed to Ibn al-Muqaffa' himself, and some rather obscure authors of allegedly Persian origin: the wise man Buzurgmihr, the physician Burzoy, and someone known as 'Ali b. al-Shāh al-Färisī. ${ }^{54}$ Since the different prefaces, which are interconnected in form and content, provide some historical embedding of the "Indian book «, the variegated premodern scholarly references to its place in history will not come as a surprise. With time, one may conclude, the prefaces became an integral part of the book's significance.

48 See the different titles mentioned in Werkmeister, Untersuchungen zum Kitäb al-Iqd al-farìd, 142-144; and Gruendler, Versions arabes de Kalïa wa-Dimna.

49 Ibn Sīnā, Fann al-shi r, ed. Badawī, 54; Ibn Rushd, Talkhịs Kitāb Arisțūtālīs fĩ al-shi r, ed. Sālim, 89.

50 There are numerous references in several volumes of Ibn Qutayba, 'Uyün al-akhbär; and Ibn 'Abd Rabbih, al-Iqd al-farìd, ed. al-'Aryān; and in one chapter of Ibn Abī 'Awn, Kitāb al-Tashbīhāt, ed. 'Abd al-Mu'îd Khān, 312-318.

51 I use "commentary" in the broad Genettian sense of metatextuality, which »unites a given text to another, of which it speaks«. Genette, Palimpsestes, trans. Newman and Doubinsky, 4.

52 Al-Yamanī, Kitāb Muḍāhāt, ed. Najm, 1-5.

53 Al-Bīrūnī, Tahquìq mā li-l-Hind, 123.

54 On the different prefaces/introductory chapters, see de Blois, Burzōy's Voyage, 24-33; and Kristó-Nagy, Pensée d'Ibn al-Muqaffa; 113-138. On the different »authors«, see part II, the section by Isabel Toral. 
The prefaces, the multitude of references, and the diverging copies of the later full manuscript texts, along with the work's contextualization within advice literature and narratives with speaking animals, and approaches to its functionality, all together suggest a conceptualization of Kalila wa-Dimna less as a book that stems from a single Arabic text, but rather as a textual tradition. This term bears first of all a methodological implication: underscoring that the numerous texts belong to one book, we tend to overlook that the very concept of »book" is a nebulous category. One usually tends to spontaneously equate the meaning of »book" with that of "text « in a totalizing material sense. Premodern writers, both commentators and copyists, however, must have had a remarkably different understanding. As a relatively open text, Kalìla wa-Dimna has a stable and meaningful core with a fairly stable significance, in clear contrast to its rather flexible and dynamic borders, extensions, and endings. The term "tradition" is an attempt to capture this ambiguity between two poles: stability on the one hand and textual flexibility on the other.

Our study of the indirect transmission thus attempts to disentangle the complexity between the two poles within the tradition, its transmission over centuries, and the reception history, in order to contribute to a more comprehensive history of Arabic literary ethics, as well as a more detailed conceptualization of premodern fictionality and knowledge-production within an Arabo-Islamic context.

\section{Kalīla wa-Dimna: Genre and Literary Context - Matthew L. Keegan}

As has been noted already, the text of Kalila and Dimna is subject to a high degree of variation both across languages and cultures and within the Arabic manuscript tradition. Copyists acted as co-authors and, in so doing, subtly reshaped the text according to their understanding of it. Thus, what constitutes the text itself is an open question. One might legitimately wonder if this high degree of variation is typical of Arabic manuscript culture. It is not. Some Arabic texts were remarkably stable, and copyists went to great lengths to preserve what they thought the "original« text was, and to point out variants on the basis of collation with other manuscripts. ${ }^{55}$

It might be suggested that the Arabic versions of Kalila and Dimna are marked by a high degree of mouvance because they belong to a genre that permitted textual flexibility, while other Arabic genres did not. The problem with this theory is that no agreement exists about how to taxonomize Kalila wa-Dimna. Neither premodern readers nor modern scholars seem to have agreed on what Kalila wa-Dimna really was. ${ }^{56}$ The tenth-century bookseller Ibn al-Nadim considers Kalìla wa-Dimna to be amusing tall-tales (khurāfät), suitable for evening entertainment like the Persian Hazār afsān or Thousand Nights, a story collection that formed the basis for the Arabic Thousand and One Nights. Ibn al-Nadim takes them to be fictive stories and does not suggest in any way that they contain useful political advice or wisdom. By contrast, the twelfth-century Persian translator Naṣr Allāh Munshì (active c. 540/1146) claimed that, after the books of law, no book was more beneficial than Kalila wa-Dimna. Although

55 See Keegan, Commentators, collators, and copyists.

56 Robert Irwin claims that it consists of »beast fables«, although he notes that no such term exists in Arabic. He is nevertheless certain that "the medieval reader could open a book of beast fables confident that his expectations would not be disappointed «. Irwin, Arabic beast fable, 36 . 
he admits that the style is full of jest, he deems it obvious that the book contains beneficial wisdom about how to manage one's affairs for rulers, élites, and commoners alike. ${ }^{57}$ Still other readers interpreted Kalila wa-Dimna's stories as allegories of the soul's descent into and subsequent extrication from the material realm..$^{58}$

Some authors attempted to claim that Kalila wa-Dimna did not originate in Middle Persian (let alone Sanskrit) but was Ibn al-Muqaffa"s creation. The aforementioned al-Yamani, who wrote a critical commentary on Kalila wa-Dimna that takes the form of a sort of "counter-anthology", accuses Ibn al-Muqaffa' of prosifying the wisdom found in Arabic poetry and then packaging it in animal stories of his own invention. Even though he criticizes Ibn al-Muqaffa', al-Yamani considers the book's wisdom to be highly beneficial when it comes to ethics, justice, and politics. ${ }^{59}$

Taking these divergent taxonomizing claims into account, it becomes problematic to assert that Kalila wa-Dimna actually belongs to one genre and is then appropriated by others. Rather, this promiscuous text came to be interpreted by its readers as a book that might be wise or foolish, superficial or symbolic. ${ }^{60}$

\section{Part III - Digital Infrastructure}

An Online Reader App for Published Versions of Kalila and Dimna - Theodore S. Beers The main task of the AnonymClassic project is to build a synoptic digital edition of the Arabic text of Kalila wa-Dimna attributed to Ibn al-Muqaffa'. This means collecting manuscripts, transcribing their contents, integrating them into a bespoke software suite, identifying recensions, creating data visualizations, and so forth. But it is also important for us to develop a general understanding of the Kalila and Dimna tradition, which spans dozens of languages and several historical periods.

Indeed, one of the ironies of Kalila and Dimna is that there has never been a proper critical edition of the Arabic text - hence the mission of our team - but there is a daunting number of published versions of works within the broader tradition. Apart from non-critical editions of the Arabic (e.g., those carried out by Louis Cheikho and 'Abd al-Wahhāb 'Azzām), ${ }^{61}$ this includes the medieval Persian adaptations of Muhammad al-Bukhārī (c. 544/1149) and Nașr Allāh Munshī (c. 540/1146); two Syriac translations, one of which is based on the lost Middle Persian text; the Sanskrit Panchatantra, as far as it can be reconstructed; ${ }^{62}$ a number of versifications; and much else. We have, furthermore, scholarly translations of many of these sources into European languages.

57 Naṣr Allāh Munshī, Kalīla va Dimna, ed. Mīnuvī, 18.

58 See al-Rāzì, Mafātīh al-ghayb 2, 249.

59 See al-Yamanī, Kitāb Mudāhāt, ed. Najm, 3-4.

60 For more on the divergent receptions of Kalila wa-Dimna, see Keegan, Its meaning lies elsewhere.

61 See Version arabe de Kalîlah et Dimnah, ed. Cheikho; and Kitāb Kalīla wa-Dimna, ed. 'Azzām.

62 See Tantrākhyāyika, ed. Hertel. 
It is often necessary for us to consult various published versions. For example, the Persian adaptations of Bukhārī and Nașr Allāh - both of which, again, date to the sixth/twelfth century - have some relevance for the textual history of the Arabic work on which they are based, since they have survived in exceptionally early copies. ${ }^{63}$ (The lack of Arabic manuscripts from before the seventh/thirteenth century has been noted several times throughout this article.) The task of cross-referencing different Kalila and Dimna-related texts, whether in the form of printed books or a library of PDF files, can become rather cumbersome.

With this in mind, we have developed a simple web application, which allows the user to select any chapter of Kalila and Dimna, and then any of the versions in which it is available, and the relevant PDF is displayed in the browser window. This is fast, easy, and accessible to members of the team wherever they may be (provided they have an Internet connection). If we happened to be working on the story of "The Owls and the Crows«, for example, and we wished to see how it is rendered in the Arabic versification of Ibn al-Habbāriyya (d. c. 509/1115), ${ }^{64}$ finding the appropriate passage would require just a few clicks (see Fig. 6 at the end of this section). To examine multiple versions for a comparative reading, one can simply open new instances of the reader app in browser tabs or windows. The utility is designed to be as lightweight as possible.

As of the beginning of May 2020, we have incorporated twenty-five versions of Kalila and Dimna (and related works) into the online reader, including adaptations or translations in the following languages: Arabic, Persian, Ottoman Turkish, Greek, Old Castilian, Hebrew, Latin, German, French, and English. More will be added over time, depending on the needs of AnonymClassic team members and collaborators.

I would like to make two final observations based on this effort. First, work that is ancillary to the main project can be surprisingly useful. The online reader app began as a convenience feature, but it has grown to a point at which it would be a valuable resource for any researcher interested in Kalila and Dimna. Second, it is worth remembering that the digital humanities are not restricted to massive undertakings. We have countless opportunities to build tools, however small, that can benefit our textual scholarship.

63 See al-Bukhārī, Dāstān-hā-yi Bìdpāy, ed. Khānlarī and Rawshan; and Naṣr Allāh Munshī, Kalìla va Dimna, ed. Mīnuvī.

64 See Ibn al-Habbāriyya, Natā 'ij al-fițna, ed. al-Asmar. 


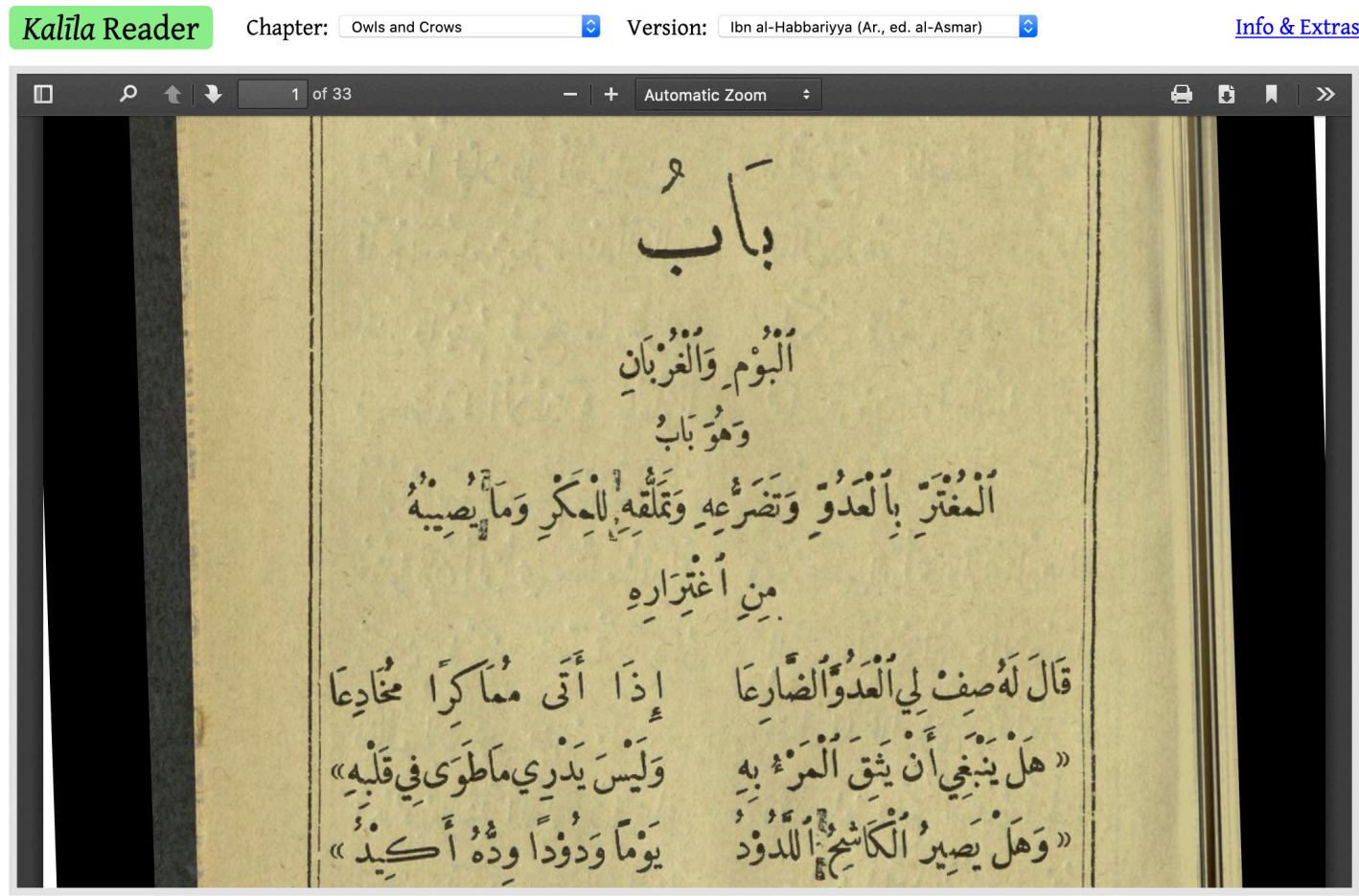

Fig. 6: A screenshot of the Kalila Reader app.

\section{Toward Usable and FAIR Software for Arabic Textual Scholarship:} An Outline of the Digital Support for the AnonymClassic Project Mahmoud Kozae and Marwa M. Ahmed

The Kalila and Dimna - AnonymClassic project seeks to assess the range of variation among selected Arabic manuscripts of this work, dating from the thirteenth to the nineteenth century, through a synoptic critical edition of chosen passages. This comprehensive study of Kalila and Dimna poses a twofold challenge for the software engineering team: (a) how to tackle the sheer volume of the data in a sensible and relatively fast manner, and (b) how to then process these data, both to mirror the continual updates in related research activities, and to create the online digital edition(s) which is the aim of the project. ${ }^{65}$

On a meta level, the AnonymClassic project serves as a pilot enterprise for an urgent question in the digital humanities: how to create tools compatible with Arabic script, and easily customizable for other non-Latin scripts (NLS). Our conditio sine qua non is adhering to FAIR principles - Free, Available, Interoperable, and Reusable - in support of a worldwide academic community.

65 We are indebted to Andreas Kaplony for permission to reuse, in part, the presentation given by Mahmoud Kozae and Rima Redwan at the International Society of Arabic Papyrology (ISAP) VII Conference. See Kozae and Redwan, Digital approaches. 
The methodological approach of the project focuses on the juxtaposition and comparison of versions: AnonymClassic is about observation, not reconstruction. The goals of the project consist in documenting the history of the text in its preserved state and its given variants, and the analysis of the context and factors of textual development. Because of a high degree of variation within the text data, a structured procedure needs to be implemented to make the process of analyzing large numbers of manuscripts possible at all. This analysis is ultimately enabled via the digital synoptic edition. The individual steps to achieve this range from digitizing to structuring the data to analyzing.

In order to understand the structure of the workflow of digital support for the project, a good start is to try to grasp the sheer data volume as such: the Kalila and Dimna text corpus appears as multi-faceted versions, embedded in multiple languages and cultures. So far, the project has actively processed more than 90 different manuscripts; this number increases on a regular basis. We currently know of some 140 manuscripts in Arabic alone. Additional language versions will be incorporated over time; our "activated " versions cover the Arabic, the Syriac, and (to an extent) the Persian traditions. The challenges thus are threefold: first, keeping the multifaceted data saved in a consistently well-formed structure; second, finding computational methods for analyzing the data according to our research questions; third, and most importantly, optimizing the aforementioned elements for a streamlined workflow. Practices from corpus linguistics, computational linguistics, data science, and software development have been adopted to model a digital infrastructure of data and tools for the project.

\section{The Workflow}

The object that is undergoing digitization is the corpus of Kalila wa-Dimna manuscripts. Work begins with data collection and curation. This means transcribing the text of a manuscript in a line-by-line manner, juxtaposing the original (i.e., images of pages) and the transcription. Codicological information must also be entered into our database: dating, state of preservation, type of script, and many other parameters. ${ }^{66}$ In order to ensure accurate documentation of all features of the text, a markup language, $\mathrm{XML},{ }^{67}$ is used rather than raw text. Markup texts offer more versatility in annotating and structuring documents. Initially, XML files encoded according to the TEI standard were the main format for saving the digitized text. ${ }^{68}$ As our corpus grew and became more complex, however, we began using an SQL database, which is easier to back up and maintain. ${ }^{69}$ Furthermore, a relational database is better suited to serve as a back end for websites and APIs, ${ }^{70}$ both of which are in the making. Additional text corpora and lexical resources are collected from public domain sources, as these are needed to test, develop, and operate machine learning algorithms for producing automated text analysis software. In addition to the manually entered data, certain information can be automatically extracted or aggregated. The most basic examples of this are word counts and lists of features notated in XML.

66 For details on manuscript description, part I, the section by Khouloud Khalfallah.

67 An abbreviation for Extensible Markup Language, which is a standard maintained by the World Wide Web Consortium. For more information, see: https://www.w3.org/XML/.

68 The "Text Encoding Initiative« provides a set of guidelines for the use of XML in philological practices. For more information, see: https://tei-c.org/.

69 An abbreviation for Structured Query Language, which is an ISO/IEC standard for data management.

70 An abbreviation for »Application Programming Interface«, which is a procedure for automated data exchange. 
A second step then involves the identification of semantic and lexical elements of the transcribed data corpus. Lexical microanalysis, i.e., lemmatization, is necessary in order to process data in Arabic. In many cases, non-Latin scripts need substantially different processing in comparison to the methods used for data provided in Latin script. (This is a difficult problem, and our work to address it remains at an early stage.) Semantic segmentation consists of identifying small semantic "units « of the text. These units are labeled individually in order to facilitate comparison. Both levels - i.e., transcriptions and manuscript parameters, and unit sequencing - are subject to ongoing updates and corrections. To streamline updating processes, for human and machine alike, is vital to the project and a core task in our software engineering.

As a third step, data are bundled into ad hoc "editions", prospectively to become our digital synoptic edition and be presented online. These are visualizations created with the help of the LERA platform. A clear representation of the data is needed to gain insights into patterns and variations. There is no predetermined hierarchical way to organize the data or visualize it, but the researcher's eye is better suited to recognizing similarities and differences among aligned portions of text. ${ }^{71}$ In addition, visualizations created from the numerical information of the units in a given passage across multiple manuscripts are helpful in making observations (which, however, may not always lead to a definite conclusion). Fig. 7 is a screenshot of the LERA platform developed at Martin Luther University of Halle-Wittenberg. ${ }^{72}$ LERA is used by the project for collating manuscripts and aligning passages. This allows the project team to perform microanalysis of the text, either in group seminars or individually. This has resulted in identifying manuscripts that have near-verbatim similarity; others that are close to each other but with frequent paraphrasing; and still others that appear to have cross-copied from several sources. ${ }^{73}$ LERA offers automatic detection of text variations, which has been successful for English, German, and French. Adjusting this functionality for Arabic is a task addressed in close cooperation between data scientists in Halle and Berlin. 


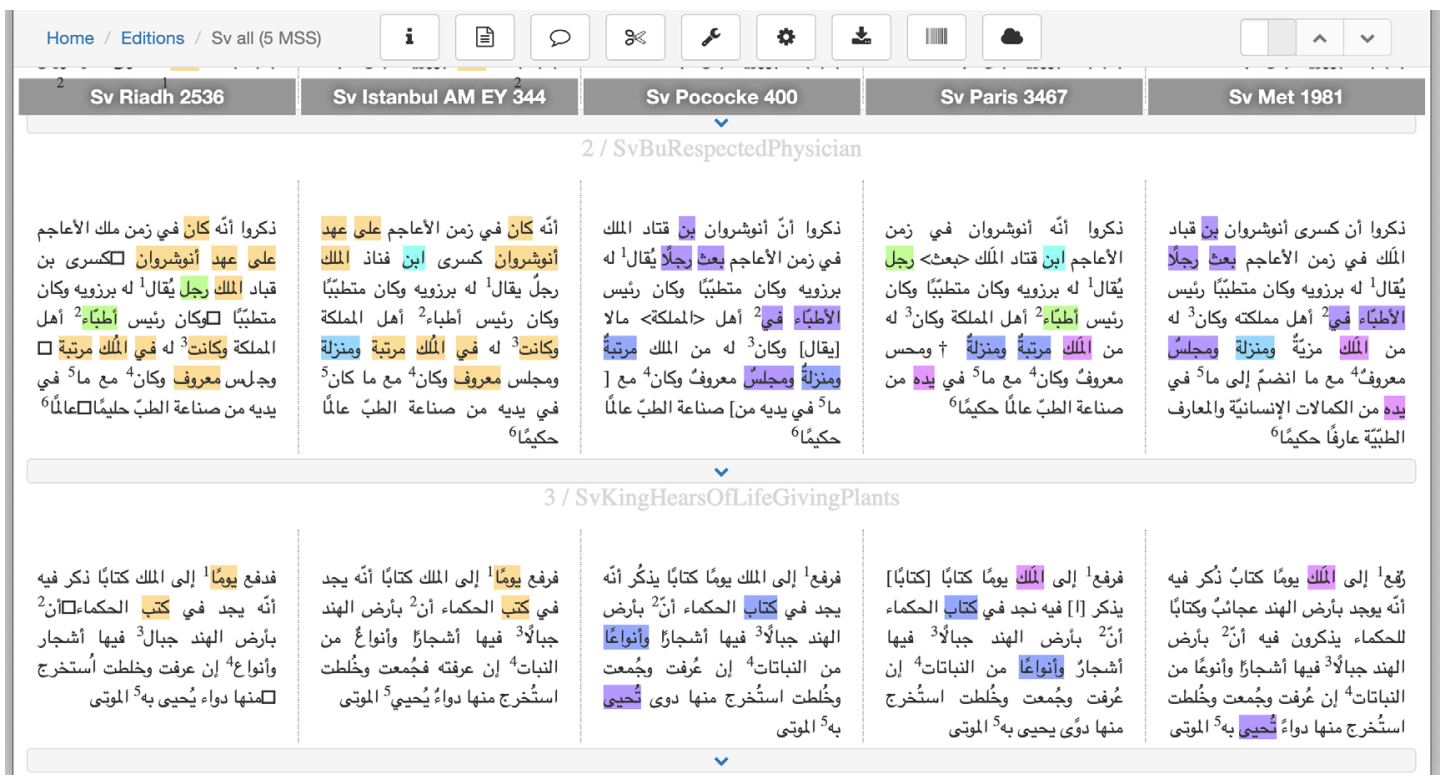

Fig 7: A screenshot of the LERA platform.

For our software engineering, there are a number of challenges to confront. Traditional editing programs tend to establish one textual witness as the "master« or "lead« text, and then provide comparisons on changes in filial witnesses. This is different in LERA and the Kalila wa-Dimna edition project: all text witnesses are treated as equal, and the corpus is seen as a network of different manifestations. Digital challenges are thus encountered in how to tackle a large volume of data. Not only are there many versions in Arabic and in other languages, but comparative work must be made possible both within a given language and crossing the boundaries of languages or translations. Future expansion of the project to further languages and/or script systems must be built in from the start.

In response to these challenges, research activities and software usage in AnonymClassic are based on a high degree of human-machine collaboration. Currently available software and methods are complemented by work on designing and building new specialized software. Human-only activities focus on discovering continua, detecting text variants, segmentation, describing manuscripts, analyzing image cycles, and beyond. Machines complement human activity in tasks related to transcription, data archiving, gathering manuscripts, and processing text annotations. Humans complement machine activity when segmenting text for collation and analysis. Machine-only activities consist mainly of the automated compilation of synoptic editions.

The basic software programs used in the project are operating systems for file management, and Microsoft Office for word processing, spreadsheets, and presentations. This is complemented by LERA and further aided by the automation of repetitive tasks using various programming languages. While searching for specialized software for editing practices, we identified a number of problems. Of the few options available, most are XML-oriented and predominantly monolithic, with user interfaces that could be better. Simple practical issues also may become time- and energy-consuming: source code is not always available, nor always intended for collaborative development. A major challenge consists in the fact that many ready-made tools are incompatible with Arabic script. Workarounds need to be developed, or digital tools created from scratch that are suited to the project. These should 
be able to interact with other projects, while ensuring longevity, both for implemented tools and for the accessibility of results.

In the AnonymClassic project, we are following an approach that could benefit the broader community of researchers. Our technology is meant to be agnostic, featuring modular architecture, and paying special attention to user interface design and usability. We aim at a solution that is compatible with Arabic and easily customizable for other non-Latin scripts, while adhering to the FAIR principles. It will take time to reach this goal, but we are on the way.

\section{Acknowledgments}

The "Kalila and Dimna - AnyonymClassic " project has received funding from the European Research Council, under the European Union's H2020-EU.1.1. - EXCELLENT SCIENCE program, Advanced Grant no. 742635. See the project website: https://www.geschkult. fu-berlin.de/en/e/kalila-wa-dimna/. 


\section{References}

\section{Manuscripts}

Beirut, Université Saint-Joseph, MS 0022(2) (1263/1847)

Berlin, Staatsbibliothek, MS Syr. 104 (Sachau 139)

Berlin, Staatsbibliothek, MS Syr. 105 (Sachau 150)

Berlin, Staatsbibliothek, MS Syr. 106 (Sachau 149)

Berlin, Staatsbibliothek, MS Wetzstein II 672 (1246/1830)

Cambridge, Corpus Christi College, Parker Library, MS 578 (eighth/fourteenth century)

Dublin, Trinity College, MS 1505

Göttingen, Niedersächsische Staats- und Universitätsbibliothek, MS Syr. 1

Istanbul, Archaeological Museum, MS EY 344 (eleventh/seventeenth century)

Istanbul, Ayasofya, MS 4095 (618/1221)

Istanbul, Ayasofya, MS 4213 (880/1476)

Istanbul, Sultan Ahmed III Library, MS 3015 (727/1327)

London, British Library, MS Or. 3900 (1166/1752-1753)

London, British Library, MS Or. 4044 (ninth/fifteenth century)

London, British Library, MS Or. 8751 (799/1369)

München, Bayerische Staatsbibliothek, MS 616 (eighth/fourteenth century)

München, Bayerische Staatsbibliothek, MS 618 (1046/1636)

Oxford, Bodleian Library, MS Arab. 253 (1227/1812)

Oxford, Bodleian Library, MS Pococke 400 (755/1354)

Paris, Bibliothèque nationale de France, MS arabe 3465 (seventh/thirteenth century)

Paris, Bibliothèque nationale de France, MS arabe 3466 (854/1450)

Paris, Bibliothèque nationale de France, MS arabe 3467 (c. 750/1350)

Paris, Bibliothèque nationale de France, MS arabe 3471 (1053/1643)

Paris, Bibliothèque nationale de France, MS arabe 3473 (eleventh/seventeenth century)

Paris, Bibliothèque nationale de France, MS arabe 5881 (1092/1681)

Rabat, Bibliothèque royale, MS 3655 (c. 1265-1280 CE)

Riyadh, King Faisal Center, MS 2407 (1103/1692)

Riyadh, King Faisal Center, MS 2536 (747/1346)

Tunis, Bibliothèque nationale de Tunisie, MS 2281 (1070/1660)

\section{Published Materials}

Assemani, Giuseppe Simone, Bibliotheca Orientalis Clementino-Vaticana 3/2 (Rome, 1725).

Bickell, Gustav, Kalilag und Damnag: Alte syrische Übersetzung des indischen Fürstenspiegels,

Text und deutsche Übersetzung (Leipzig, 1876).

al-Bīrūnī, Abū al-Rayḥān, Taḥìq mā li-l-Hind min maqūla maqbūla fĩ al-'aql aw mardhūla

(Hyderabad, 1958).

de Blois, François, Burzōy's Voyage to India and the Origin of the Book of Kalilah wa Dimnah

(London, 1990).

al-Bukhārī, Muḥammad b. 'Abdallāh, Dāstān-hà-yi Bìdpāy, ed. Parvīz Nātil Khānlarī and Muhammad Rawshan (Tehran, 1982).

Dagenais, Jean, The Ethics of Reading in Manuscript Culture (Princeton, 1994). 
Few, Stephen, Data visualization for human perception, in: Interaction Design Foundation, The Encyclopedia of Human-Computer Interaction (second edition) (2013). Accessed on 19th May 2020: https://www.interaction-design.org/literature/book/the-encyclopedia-of-human-computer-interaction-2nd-ed/data-visualization-for-human-perception.

Forster, Regula, Barlaam and Josaphat, in: Kate Fleet, Gudrun Krämer, Denis Matringe, John Nawas and Everett Rowson (eds.), Encyclopædia of Islam, THREE (2012). Accessed on 19th May 2020: https://dx.doi.org/10.1163/1573-3912_ei3_COM_24301.

Genette, Gérard, Palimpsestes: Literature in the Second Degree, trans. Chana Newman and Claude Doubinsky (Lincoln, NE, 1997).

Gruendler, Beatrice, The Arabic anonymous in a world classic (acronym: AnonymClassic): Presentation of a research project, Geschichte der Germanistik 51/52 (2017) 156-157.

Gruendler, Beatrice, A rat and its redactors: Silent co-authorship in Kalila wa-Dimna, in: Annie Vernay-Nouri and Eloïse Brac de la Perrière (eds.), The Journeys of Kalila and Dimna: Itineraries of Fables in the Arts and Literatures of the Islamic World (Leiden, forthcoming).

Gruendler, Beatrice, Les versions arabes de Kalila wa-Dimna: Une transmission et une circulation mouvantes, in: Marie-Sol Ortola (ed.), Énoncés sapientiels et littérature exemplaire: Une intertextualité complexe (Nancy, 2013) 387-418.

Ibn 'Abd Rabbih, al-Iqd al-farìd, 4 vols., ed. Muhammad Sa'īd al-'Aryān (Cairo, 1940).

Ibn Abī 'Awn, Kitāb al-Tashbīhāt, ed. Muḥammad 'Abd al-Mu'īd Khān (Cambridge, 1950).

Ibn al-Habbāriyya, Muḥammad b. Muhammad, Kitāb Natā ỉj al-fiṭna fĩ nazm Kalīla wa-Dimna, ed. Ni'mat Allāh al-Asmar (Ba'abdā, Lebanon, 1900).

Ibn al-Nadìm, Muhammad b. Ishạa, Kitāb al-Fihrist, 4 vols. in 2, ed. Ayman Fu'ād al-Sayyid (London, 2009).

Ibn Qutayba, 'Uyün al-akhbār, 4 vols. (Cairo, 1925-1930).

Ibn Rushd, Talkhịs Kitāb Arisțūtālìs fĩ al-shi r, ed. Muhammad Salīm Sālim (Cairo, 1971).

Ibn Sīnā, Fann al-shir r, ed. 'Abd al-Raḥman Badawì (Cairo, 1953).

Irwin, Robert, The Arabic beast fable, Journal of the Warburg and Courtauld Institutes 55 (1992) 36-50.

al-Jāḥiẓ, Abū 'Uthmān, Kitāb al-Hayawān, 7 vols. in 4, ed. 'Abd al-Salām M. Hārūn (Cairo, 1938-1945).

Keegan, Matthew L., Commentators, collators, and copyists: Interpreting manuscript variation in the exordium of al-Ḥarīrī's Maqāmāt, in: Joseph E. Lowry and Shawkat M. Toorawa (eds.), Arabic Humanities, Islamic Thought: Essays in Honor of Everett K. Rowson (Leiden, 2017) 295-316.

Keegan, Matthew L., Its meaning lies elsewhere: The vagaries of Kalila and Dimna (forthcoming).

Kitāb Kalìla wa-Dimna, ed. 'Abd al-Wahhāb 'Azzām (Cairo, 1941).

Kozae, Mahmoud and Rima Redwan, Digital approaches to a mutable textual tradition: Kalìla wa-Dimna in manuscripts from the 13th to 19th centuries, in: International Society of Arabic Papyrology (ISAP) VII Conference Proceedings (forthcoming).

Kristó-Nagy, István, La pensée d'Ibn al-Muqaffa: "Un agent double» dans le monde persan et arabe (Paris, 2013).

Marlow, Louise, Advice and advice literature, in: Kate Fleet, Gudrun Krämer, Denis Matringe, John Nawas and Everett Rowson (eds.), Encyclopædia of Islam, THREE (2007). Accessed on 19th May 2020: https://dx.doi.org/10.1163/1573-3912_ei3_COM_oo26.

Naṣr Allāh Munshī, Abū al-Ma ālī, Kalīla va Dimna, ed. Mujtabā Mīnuvī (Tehran, 1964). 
Nau, François, Un manuscrit de Mgr Graffin: l'Ancien manuscrit du Kalila et Dimna syriaque, Revue de l'Orient chrétien 16 (1911) 200-204.

al-Rāzī, Fakhr al-Dīn, Mafätīh al-ghayb, 32 vols. in 16 (Beirut, 1981).

Schoeler, Gregor, Verfasser und Titel des dem Ğāhiz zugeschriebenen sog. Kitāa al-Tāğ, Zeitschrift der Deutschen Morgenländischen Gesellschaft 130 (1980) 217-225.

Schulthess, Friedrich, Kalila und Dimna: Syrisch und Deutsch, 2 vols. (Berlin, 1911).

Schulthess, Sara, Les manuscrits arabes des lettres de Paul: La reprise d'un champ de recherche négligé. Unpublished PhD thesis (Radboud Universiteit, 2016). Online component: https:// digi.vatlib.it/view/MSS_Vat.ar.13.

Schütz, Susanne and Marcus Pöckelmann, LERA: Explorative Analyse komplexer Textvarianten in Editionsphilologie und Diskursanalyse, in: Book of Abstracts of the Third Annual Conference of Digital Humanities for German-Speaking Regions (2016) 239-243.

Tanträkhyāyika: Die älteste Fassung des Pañcatantra nach den Handschriften beider Rezensionen, 2 vols., ed. Johannes Hertel (Berlin, 1909).

Toral-Niehoff, Isabel, Die Legende "Barlaam und Josaphat « in der arabisch-muslimischen Literatur: Ein arabistischer Beitrag zur »Barlaam-Frage«, Die Welt des Orients 31 (2000) 110-144.

Toury, Gideon, Descriptive Translation Studies: And Beyond (Amsterdam, 2012).

Vernay-Nouri, Annie and Eloïse Brac de la Perrière (eds.), The Journeys of Kalila and Dimna: Itineraries of Fables in the Arts and Literatures of the Islamic World (Leiden, forthcoming).

La version arabe de Kalîlah et Dimnah, ed. Louis Cheikho (Beirut, 1905).

Werkmeister, Walter, Untersuchungen zum Kitäb al-Iqd al-farìd des Andalusiers Ibn 'Abd Rabbih (246/860-328/940): Ein Beitrag zur arabischen Literaturgeschichte (Berlin, 1983).

Wright, William, The Book of Kalilah and Dimnah or: The Fables of Bidpai (Oxford, 1884).

al-Yamanī, Abū 'Abdallāh Muhammad, Kitāb Mudāhāt amthāl Kitāb Kalìla wa-Dimna bi-mā ashbahahā min ash 'àr al-'arab, ed. Muhammad Y. Najm (Beirut, 1961).

al-Ya qūbì, Aḥmad b. Abì Ya qūb, Tärìkh, 2 vols., ed. M. Th. Houtsma (Leiden, 1860).

al-Ya 'qūbī, Aḥmad b. Abì Ya 'qūb, The Works of Ibn Wädih al-Ya quībī, 3 vols., ed. and trans. Matthew S. Gordon, Chase F. Robinson, Everett K. Rowson, and Michael Fishbein (Leiden, 2018).

\section{List of Figures}

Fig. 1: London, British Library, MS Or. 3900 (1166/1752-1753), fol. 1v.

Fig. 2(a): Oxford, Bodleian, MS Pococke 400 (755/1354), fol. 46r.

Fig. 2(b): Paris, BnF, MS arabe 3467 (c. 750/1350), fol. 15v.

Fig. 2(c): München, BStB, MS 616 (first half of the eighth/fourteenth century), fol. 48v.

Fig. 3(a): Rabat, Br, MS 3655 (c. 1265-1280 CE), fol. 100v.

Fig. 3(b): Istanbul, AM, MS EY 344 (eleventh/seventeenth century), fol. 132v.

Fig. 3(c): Cambridge, CCC, Parker Lib., MS 578 (eighth/fourteenth century), fol. 108r.

Fig. 3(d): Paris, BnF, MS arabe 5881 (1092/1681), fol. 75r.

Figs. 4(a-b): Tabulation of semantic units in the preface of Ibn al-Muqaffa'

Fig. 5: An example of cross-copying in $\mathrm{P}_{5881}$

Fig. 6: A screenshot of the Kalila Reader app.

Fig. 7: A screenshot of the LERA platform. 